\title{
Private Investment and the Effects of Decentralisation and Regional Competition between Mexican Cities
}

\author{
Ibarra-Armenta Cristina Isabel \\ Faculty of Economics and Social Sciences, Autonomous University of Sinaloa, 80010, Culiacán, Sinaloa, Mexico
}

Copyright $\bigcirc 2018$ by authors, all rights reserved. Authors agree that this article remains permanently open access under the terms of the Creative Commons Attribution License 4.0 International License

\begin{abstract}
The increasing mobility of capital raises competition between territories in order to attract it within their jurisdiction. Since 1994, the decentralisation process in Mexico has been accelerated by providing municipalities with greater funds. In parallel, Mexican municipalities have participated more actively on policymaking. Both facts should have allowed municipalities to enhance competitive advantages and increase their attractiveness. In spite of the increasing resources and local participation in policymaking, their effects on investment growth have not been tested yet. In addition, even when municipal governments cannot offer significant pecuniary incentives to firms, they use other means to boost investment. The effects of such regional policies to attract firms have not been tested either. This work is aimed to find out the extent to which the funds exerted at the local level have induced private investment growth. In addition, the effects of regional competition are tested. A panel data analysis is carried out using data for 63 Metropolitan Areas/cities for the period 1993-2008. The estimations are divided into domestic and foreign firms, and total and manufacturing firms, in turn. The results suggest that, two major spending items, namely Economic fostering and subsidies, and Public infrastructure investment, have a substantial effect on private capital. Moreover, the effects are larger over foreign firms, especially in manufacturing. In addition, competition strategies matter for private investment growth.
\end{abstract}

Keywords Private Investment, Decentralisation Effects, Regional Competition, Local-Public Expenditures

\section{Introduction}

It is well known that some cities are more successful than others. Some are in decay while others in boom. The former are not highly attractive for new FDI flows and human capital, and they could be incapable to retain the established investment and inhabitants. Successful cities are attractive for firms and people and can be also sticky places given their business environment and living conditions [1]. Within competitiveness literature, cities can be called winners or losers according to their economic performance. When the same paths remain in the mid and long-terms, economic gains tend to concentrate in few cities. This is especially true for developing countries where urban systems tend to be highly uneven [2].

Mexico has experienced an important process of economic liberalisation bringing about economic growth and increments of the income level. Nonetheless, the regional outcomes are disparate, indeed regional income inequalities have been increasing after 1980, when the economic liberalisation started [3]. At the same time, a decentralisation process has been undertaken, and local governments have more responsibilities to participate on economic planning, and provision of public infrastructure, education and health. Local governments in Mexico foster economic growth by means of economic planning, support to national and foreign firms to ease the paperwork and obtain fiscal benefits, credits and incentives. They may also promote the regions and make diverse agreements to enhance economic growth. Besides, municipal government invest on infrastructure. All these actions depend not only on the resources spent, but on the managerial abilities and the efforts carried out by the local key actors.

The fiscal and political decentralisation have had the aim to allow and encourage the participation from local and regional government to attend their specific needs [4]. In other words, Mexican federal government seeks to boost the bottom-up approach in policymaking, given the possible benefits of decreasing regional disparities pointed by various scholars and international organisations such as OECD and ECLAC [5]. On the contrary, greater decentralisation could also increase jurisdictional competition for resources and reinforce regional inequalities [6, 7], especially in developing countries [8].Thus, increasing local participation may lead to regional competition, in which wealthier cities have an 
advantageous position against the poorer.

The total revenues from Mexican municipalities increased on $281 \%$ in the period 1993 to 2015 . From there, the main expenditure items are current expenditures, Economic Fostering and subsidies (EF\&S), and Public infrastructure investment (PII) with average shares of 52\%, $9 \%$ and $25 \%$, respectively. Namely, the municipalities spend a significant share of their revenues on actions potentially related to economic development strategies and private investment fostering. Moreover, compared to 1993 by 2015 the total budget for EF\&S had increased in $461 \%$, while PII did it in $420 \%$. Consequently, these are picked as the interest variables standing for local actions related to private investment boosting ${ }^{1}$. In spite of the increasing efforts and pecuniary resources spent by local governments, their effects over economic performance have not been tested yet. The contribution of this paper is to find whether the expenditures on the two expenditure chapters have influenced the private investment growth rates. In addition, this work contributes to the empirical literature of regional competition with four variables to measure the importance of competition policies. Considering that the literature suggest that regions/cities in competition are those geographically close and/or those with similar economic specialisation $[9,10]$ and governments play a significant role by designing competition strategies and strengthening local competitive capacities, four variables are added to test competition by economic specialisation and geographic location, according to the two expenditure items considered.

Using panel data analysis for 63 cities from 1993 to 2008 it was found that municipal expenditures constitute a significant driver for private investment. The results showed that domestic firms tend to benefit more from EF\&S expenditure, meanwhile foreign firms benefit from PII. As regard with regional competition variables, the results suggest that cities investing more on PII than their tested competitors, have enjoyed larger private investments.

In sum, given that expenditure from local governments proved to be significantly enhancing private investment, it can be said that the decentralisation in Mexico has endowed local governments to pursue economic growth to a good extent.

\section{Materials and Methods}

\subsection{Data}

Getting statistical data for small municipalities in

\footnotetext{
1 The author recognizes that similar actions are carried out at state and federal level, yet they are out of the scope of this paper, which is narrowed to local governments
}

Mexico is hard, and sometimes impossible, particularly for public infrastructure endowments. Moreover, most of economic activity is concentrated in big cities. Likewise, rural and small municipalities do not have the financial resources or administrative capacity to undertake their own economic development programs; at most they manage to address the everyday tasks [4]. Hence, the sample includes medium and big cities, which according to Sobrino [11] are all the ones above 100, 000 inhabitants, yet the limit has been lowered to 80,000 inhabitants in order to pick at least one city per state ${ }^{2}$. Some of them had been established as metropolitan areas given their proximity and interaction with other surrounding urban areas. These Metropolitan areas were defined by CONAPO (National Bureau for Population) in 2005. In total, by 2005 there were 67 cities bigger than 80,000 inhabitants, encompassing 325 municipalities in total, which represented about $62 \%$ of the national population. Nonetheless, Mexico City, and the cities in the most important oil producers states -Tabasco and Campechehave been taken out from the sample to diminish bias in the results. Mexico City is a huge economic centre with its own dynamism. The oil producers have big amounts of foreign investment and high GDP per capita, yet their dynamism and decentralized funds relies on the natural resources existent rather than in local policies. Many other researchers usually exclude oil producers and Mexico City when doing empirical models in Mexico, see for instance $[3,11-13]$. In sum, the sample accounts for most major cities in Mexico, except those mentioned above. In that way, the sample contributed with about $65 \%$ of the national Total Gross Product $\left(\mathrm{TGP}^{3}\right)$ in the period.

The data employed here comes from different databases published by the National Bureau of Statistics (INEGI). For production and firms characteristics the Economic Censuses by INEGI are used. They constitute the richer database at firm level, nevertheless, given confidentiality problems, firms cannot be analysed as units of study. In this work, the data is aggregated at the city level, including 17 industries, which encompass manufacturing production, trade and services.

The Economic Census is a survey that is carried out every five years in Mexico. There is information about production, employment, investment, expenditures, taxes, and revenues for domestic and foreign/joint venture firms. This is the only survey providing information for joint-venture/foreign and domestic firms at the municipal/city level from 1998 onwards. Thus, when possible, the estimations are divided in domestic and

\footnotetext{
2 This is to include Tlaxcala as it is very small in terms of population and territory, yet it receives significant investment given their geographic position in the centre region where most population and investment are located.

${ }^{3}$ TGP given the methodology difference between Economic Censuses and National Accounts, this variable is used as equivalent to GDP.
} 
foreign firms. The outlays EFS\& and PI are expected to affect differently manufacturing firms and the rest, this is trade and services, because most incentives are granted to manufacturing firms, and services or trade firms might need different type of public infrastructure. Thus, the models are also estimated separating manufacturing firms and the rest.

\subsection{The Model}

The proposed baseline equation is the following:

$$
P_{i t}=\alpha+\mu_{i}+\theta_{t}+\beta X_{i t}+E F \& S_{i t}+P I I_{i t}+\varepsilon_{i t}
$$

Where $P_{i t}$ stands for the new private investment with respect to the previous year for city $i$ in the year $t, \mu_{i}$ stands for the time invariant characteristics of each city, this is city Fixed Effects (FE). $\theta_{t}$ is the time dummy. $X_{i t}$ is a vector of control variables for city $i$ in the year $t$. $E F \& S_{i t}$ is one of the interest variables for expenditures on Economic Fostering activities per employee for city $i$ in the year $t . P I I_{i t}$ is the other interest variable, Public Investment on Infrastructure per employee for city $i$ in the year $t$. $\varepsilon_{i t}$ is the error term. The control variables are specified in the following section.

For the estimation method, first, given that these are regional units, it is necessary to account for $\mathrm{FE}$ in the estimations. Additionally, cities within the same country might be affected by the performance of other cities to a certain extent. This can cause violation of one of the assumptions for panel data models, namely, independence across panels. Likewise, external shocks such as the US crisis or the macroeconomic policy, which cannot be modelled, can violate independency across panels as well [14]. Cross section correlation can be partially treated introducing time dummies, yet it entails that correlation for every pair of units are the same [15].

Driscoll and Kraay [14] pointed out that even the modest presence of spatial dependence could cause an important bias in the OLS standard errors, because the orthogonality conditions in the variance matrix are violated. They propose a model assuming a spatial and temporal correlation in the residuals. The degree of dependence between two-cross sectional units depends on the size of the constant factors and their persistence over the time. The covariance matrix is robust to heteroskedasticity. When proposed, this method was based on asymptotic properties and it was recommended for large samples [14]. Nevertheless, for its implementation in Stata, the method was improved, and proved to work well with small samples, especially for large $\mathrm{N}$ and small $\mathrm{T}$ panels [15]; the Monte Carlo simulations were done with even a $\mathrm{T}=5$. The method applies a Newey-West type correction to the sequence of cross-sectional averages of the moment conditions. This allows that the estimator is consistent independently of the size of $\mathrm{N}$. The DK estimator is also consistent in the presence of autocorrelation, although if no cross-section dependence is found, it is recommended to use other estimation methods to deal with this particular issue.

There are other methods available in cases of larger panels, especially when $\mathrm{N}$ is close to $\mathrm{T}$, such as the estimators based on feasible generalised least squares. However given the shape of this data set -large $\mathrm{N}$ and small T- such methods are not appropriated. Also there is the panel-corrected standard errors method which uses pool OLS, but it is less convenient for this data set, since FE cannot be estimated. The common correlated effects (CCE) method proposed by Chudick, Pesaran and Tosetti [16] is not feasible for this data set either, given the small $\mathrm{T}$ available. Moreover, it is more adequate when lagged dependent variables are used, and the data presents autocorrelation; neither case is present in the proposed model.

In consequence in order to decide which $\mathrm{FE}$ method to employ, cross section dependence was tested using the tests proposed by De Hoyos and Sarafidis [17]. It was found cross-section dependence; thus the estimation method must deal with cross-section dependence. In this manner, taking into account the mentioned advantages of the DK estimator I believe it is the most appropriate in this case.

Other concern in the data is the possibility of endogeneity of the interest variables. It is possible that the more private investment occurred in one year, the more money exerted on PII and EF\&S by the governments; and no the other way around, especially if there are subsidies given. However, as said before, for EF\&S it is important to remark subsidies constitute a small share of the total expenditure item. Also, the expenditures comprise the budget of public offices and, as they continue to work regardless the private investment exerted, in consequence this share is not expected to be endogenous. Besides, given the type of expenditures, it is also likely that the expenditures influence only on future investment decisions that occur months or years after the government has exerted the money. Considering data availability it is used the $3^{\text {rd }} \mathrm{lag}^{4}$, which might help to reduce endogeneity issues.

Nonetheless, to check consistency of these variables difference GMM estimations are performed. It has been chosen differences instead of systems since it is efficient enough when only right hand variables are believed to be endogenous. It has been suggested by Bond et al [18] that Systems GMM are more efficient when the time series are persistent. Nevertheless, whether the dependent variable is not lagged, no persistent series are present and there is only presence of endogeneity of right hand variables the Sargan test of Overidentifying restrictions and related tests are enough to assess the validity of the instruments, which can be simply the lags of the instrumented variables [18]. In

\footnotetext{
4 Due to data availability taking further lags it not posible, witout missing one year obsevation for thw whole panel
} 
addition, in order to avoid losing observations and suffer bias given the existing gaps in the panels, forward orthogonal deviations are used as recommended by Roodman [19]. In this way, two types of instruments were used, the GMM-style, using forward orthogonal deviations, and the IV-style in which the fifth-lag of the interest variables are also used as instruments.

\subsection{The Variables}

The dependent variable in the model is the new private investment; the indicator for such variable employed here is the new investment per year, as given in the Economic Census. The investment corresponds to the total investment made by the firm during the previous year January to December-. For comparison purposes across the censuses, it was found to be the best indicator for private investment.

For some variables the natural logarithm is used in order to find the elasticity between the interest variables and the new private investment. The monetary variables are expressed in MXN pesos at constant prices of 2003.

For right hand variables, considering those frequently used in empirical works, the model controls for some regional features such as market size, labour force availability, public infrastructure, health, education, economic structure and economic specialisation degree.

\subsubsection{Economic fostering and subsidies (EF\&S)}

Within the regional competitiveness and regional competition literature economic policies to boost private investment can be classified into soft incentives-based and hard/competitive-enhancing strategies according to the type of competitive advantage fostered [20]. The former encompasses all types of fiscal incentives given to firms, which are scarce in Mexican municipalities, as well as the solely marketing actions; for instance, participation in economic and tourism fairs without any significant improvement to the local business environment. The hard strategies regard with any action improving the local business environment which can covers from institutional innovations, firms' support, public infrastructure and security improvements, as well as the implementation of network enhancing policies which are generally identified as the drivers for mid and long-term competitiveness [21-22].

This expenditure item contains the total expenditures of the municipal government in economic fostering, subsidies and transfers to firms, people and public offices, described above. Namely, it encompasses the budgets destined to the local economic development, as well as tourism offices which carry out all type of business promotion, marketing, and firms' support among other administrative tasks on behalf of the municipality related to economic development. As regards to subsidies and transfers, it should be highlighted that given the budgets constraints, even in big cities, the incentives granted by municipal governments frequently consist in tax/local fees exemptions, rather than in huge cash transfers, similarly to other countries [23]. In this way, the variable accounts for different potential efforts undertaken by the municipal governments to boost the economic performance. Here the budget for soft and hard policies are mixed. Yet, in average, the incentives and transfers constitute no more than $30 \%$ of the expenditures. Consequently, the expenditures are mainly related to potential hard strategies.

In order to take into account the size of the municipality, the variable used in the models is the expenditure done per employee in the city. The number of employees is taken into account, instead of the population, given that the spending might be more related to the level of economic activity and employment, rather than just the size of the population. The variable is expected to have positively affect private investment. It is important to highlight that domestic and foreign firms receive different types of support. Municipalities usually support domestic firms, thus, their expenditures might have larger effects in domestic investment increments than on foreign investment.

\subsubsection{Public investment on infrastructure (PII)}

This expenditure item registers budget for maintenance and construction of public infrastructure exterted by the municipality. Different kinds of infrastructure could be built, such as roads, pavement, drainage, water feeds, etc. This item also contains the non-physical investment which encompasses security and some other expenditures to foster private investment, not involving grants. Yet, most of the expenditures regards with physical infrastructure. In this manner, the expenditure item is related with hard regional competitiveness/competition strategies. Similarly to the EF\&S variable, to take into account the size of the city the variable used in the models is the total expenditure on PII per employee in the city.

\subsubsection{Economic diversity/specialisation}

Some industries might growth faster in a specialised city due to the intra-industry spillovers. But others could benefit more from inter-industry interactions, and thus grow more in diversified cities [24]. Additionally, the spillovers effects from the same or other industries could influence the investment decision of firms [25]. A way to control for this is to include a variable for economic specialisation. An absolute indicator is used to control for diversity inside the city, regardless to how important is the production of such city in the national scale. The specialisation level is measured according to the size of a specific industry respect to the total TGP in the same city. In this way, the share of the industry with highest contribution to the city's TGP is used. When the number is high, it can be said that the city is highly specialised. 
When the number is low the city has more economic diversity. The extreme case would be a city that is specialised to only one industry, the indicator would be 1 . On the opposite, if the city is evenly diversified and all industries were equally important, the lowest number would be $1 / 17=0.0588$, considering the 17 industries included.

\subsubsection{Public Infrastructure stock index}

An index was built using data of the available public infrastructure on electricity, water, roads, communications and drainage system. On empirical research, infrastructure indicators vary a lot. Some researchers use the landlines available; others use the data of the existing stock; while others use expenditures [26]. Nonetheless, given the corruption or differences in needs, similar investment levels do not entails similar endowments of infrastructure stock. Thus it is important to add indicators of the stock, when available [27-29]. As regards with the expected sign, public infrastructure is positively related to investment increments [30]. However, according to Fuentes [27], in Mexico not all the cities with relatively better infrastructure endowments are the most successful ones because cities with high economic growth attract more population and firms, making difficult for the local authorities to respond fast to the infrastructure needs, especially in the north. In other words, cities with more dynamic growth might have more infrastructure needs.

\subsubsection{Economic Active Population}

As a growth model approach it is useful to control for the labour force availability, which should be positively related to private investment. This is the population over 12 years old in the city.

\subsubsection{Manufacturing employment}

This is a control variable for economic structure which might also influence the private investment growth rate [31]. Cities specialised in manufacturing activities might be more dynamic than others. On the other side, if the city relies a lot on few industries, it might be vulnerable to external shocks. The variable is the share of total employees in manufacturing activities over the total employment in the city.

\subsubsection{Market size}

As a growth model approach it is necessary to control for the market size. According to neoclassic theory, cities with larger GDP are expected to grow at a slower pace than those with smaller size [32]. The variable is the total TGP in the city.

\subsubsection{Market potential}

In addition to the local market size, it is also important to consider the potential market, that is, the income from geographically close cities. The market potential within a radius of $300 \mathrm{~km}$ travel distance around the city of reference is included in the models as well. The travel distance has been decided considering that Mexico is a big country, and most of cities are located at least one-hour drive from each other in the centre region, and more than two in the north region. Thus it is sensible to take an area which encompasses between 3 and 4 hours of travel time. The market potential is calculated with the sum of the total TGP from all cities within $300 \mathrm{~km}$ travel distance from the reference city divided by the distance between them.

$$
\begin{gathered}
M P_{i j}=\sum_{i}^{n} T G P_{i} / d_{i j} \\
\operatorname{MPCity}_{\mathrm{j}}=\sum_{\mathrm{i}}^{\mathrm{n}} \frac{\mathrm{TGP}_{\mathrm{i}}}{\mathrm{d}_{\mathrm{ji}}} \mathrm{i} \neq \mathrm{j} i \neq j \quad i=1 \ldots n
\end{gathered}
$$

$\forall_{i}$ Within $300 \mathrm{~km}$ travel distance from city $j$

$d_{i j}^{i}$ Is the distance in $\mathrm{Km}$ between city $i$ and city $j$

\subsubsection{Foreign market potential}

Given that many firms located in the bordering regions intend to supply the United States (US) market, a foreign market potential variable have been also estimated. The variable is estimated as follows:

$$
U S M P_{i t}=\sum_{i}^{n} U S G D P \times\left(1 / D i s_{i j}\right)
$$

Where $U S M P_{i t}$ is the market potential to the US of the city $i$ in the year $t$. USGDP is the total GDP of the four bordering states in the US, that is, Texas, California, Arizona and New Mexico. Only those states are considered, because they might be the most important given their geographical proximity. According to Mexican officials, these markets highly influence firms' location decisions. Firms interested in exporting to California or Arizona, settle in the northwest Mexican region. Firms willing to supply markets in the east may locate in the Mexican east bordering cities. It is assumed that the further, the less importance is given to the US market. Hence, the USGDP is multiplied by the inverted distance to the nearest border-city $j$ from the reference city $i$. More specifically, for cities in the west side, the distance is estimated to Calexico and San Diego, in California, and Naco, in Arizona. For those to the East, the reference cities are Brownville and Laredo, in Texas. The distance was calculated using real distances with Google maps application, measuring distance in $\mathrm{Km}$.

\subsubsection{Infant mortality rate}

It is an infant mortality rate per 1000 births. This is a control variable for health and general wellbeing, which is related to better living conditions, as well as better human capital [26]. It is well established that quality of life and health is also an important driver for investment [33-37]. Other common indicators used are the number of doctors or hospital beds per 1000 inhabitants, which shows no only health, but also quality in health services, so it is highly used in growth studies [26]. However infant mortality rate 
is the only health indicator available for all cities in the period. It is expected a negative sign, that is, the smaller mortality rate, the better health conditions, and the higher investment levels.

\subsubsection{Geographic competition}

This is a variable to test whether there exists competition between geographically close cities. Close cities tend to have similar economic structure, general amenities, social conditions, culture and other satisfactors, especially within the same state. However, capital cities in each state tend to be favoured with more public resources; therefore many of them have the best infrastructure, labour force, universities and other urban amenities in each state. In view of that, cities might compete for investments first against the capital in the state to get pecuniary resources as well as political support. Whether competition exists, governments spending more than their direct competitors, geographically close in this case, should be more attractive for private investment, assuming that cities in the same region/state might observe similar conditions, according to Camagni [37] cities are likely to lose resources if they are performing worse than their relational partners.

Consequently, the variable is calculated with the differences in expenditures on EF\&S and PII between the reference city and the cities within $300 \mathrm{~km}$, accordingly to what has been considered to be within the market potential in the respective variable, weighted by employment level. The formula is as follows:

$$
\text { Gcompetition }_{i}=\sum_{j}^{n}\left(E F \& \operatorname{Spe}_{i}-E F \& \operatorname{Spe}_{j}\right)
$$

Where $j=1 \ldots(n-1)$ and $i \neq j$

$\forall j$ Within $300 \mathrm{Km}$, travel distance.

$E F \& S p e_{i}$ are the total expenditures exerted by the municipality $i$ on Economic Fostering and Subsidies per employee. $E F \& S p e_{j}$ are the respective expenditures of the cities considered in competition. Similar estimations are carried out using PII per employee.

If the sum of differences is positive, it means that city $i$ is investing more than its neighbours. Therefore, should this variable have a positive sign it indicates that, the bigger the difference the more investment growth. In other words it is been meaningful to invest more money than close cities to foster more investment. A positive sign is expected.

2.3.12. Competition by economic specialisation
This variable tests whether competition exists between cities with similar economic specialisation. To define the cities' specialisation, the economic structure is divided into 17 industries. The city is considered to be specialised in the economic activity that has the larger share of the TGP. Similar to Gcompetition, two variables are built, one using EF\&S and the other using PII expenditures, weighted by employment levels.

This is the formula:

$$
\text { Scompetition }_{i}=\sum_{j}^{n}\left(E F \& S_{\text {Spe }}-E F \& S_{i} e_{j}\right)
$$

Where $j=1 \ldots(n-1)$ and $i \neq j$

$\forall j$ With the same economic specialisation than city i.

$E F \& S p e_{i}$ are the total expenditures exerted by the municipality i in Economic Fostering and Subsidies per employee. $E F \& S p e_{j}$ are the respective expenditures of the $\mathrm{j}$ cities considered in competition. Similar estimations are carried out using PII per employee.

Should the total sum be positive, that city $i$ invests more money than the other cities with the same economic specialisation. A positive sign is expected given that firms willing to expand their markets or to move out, might seek for better urban amenities, infrastructure or support to firms.

Besides of the previous variables, some interaction terms are added to test possible scenarios in which the investment of local governments would have a greater influence on firms' investment.

\subsubsection{Manufacturing employment*EF\&S/PII}

A large proportion of the efforts to encourage investment are aimed to foster the manufacturing firms, since it is believed that they would boost economic development faster than other industries, especially firms with high-tech profile. In the case of Mexico, the automotive and aerospace became the panacea for development, which frequently look for more suppliers and completing production processes [38]. Moreover, cities with larger manufacturing production may also attract all kind of firms, owing to the general advantages generated in the city $[39,40]$. In view of that this variable tests for additional effects of regional policies in cities depending on the presence of manufacturing firms.

The summary statistics of the variables are included in table 1 . 
Table 1. Variables summary statistics

\begin{tabular}{cccccc}
\hline Variable & Obs & Mean & Standard deviation & Min & Max \\
\hline New private investment. Thousands (MXN) & 252 & $\$ 1,381,418.00$ & 2454620 & $-\$ 1,630,061.00$ & $\$ 20,800,000.00$ \\
Economic diversion/specialisation index & 252 & 0.4774761 & 0.1602751 & 0.1650831 & 0.9466147 \\
Economic Active Population & 252 & 452832 & 482535.5 & 39348 & 3185553 \\
Infant mortality rate per 1000 births & 252 & 13.96909 & 5.56099 & 2.119626 & 33.83838 \\
Economic Fostering and subsidies per employee & 252 & $\$ 140.99$ & 152.24 & $\$ 0.00$ & $\$ 1,082.36$ \\
Economic Fostering and subsidies per employee (T-3) & 252 & $\$ 102.85$ & 134.21 & $\$ 0.00$ & $\$ 1,163.32$ \\
Public Physical Investment per employee & 252 & $\$ 503.14$ & 747.24 & $\$ 0.00$ & $\$ 9,887.51$ \\
Public Physical Investment per employee (T-3) & 252 & $\$ 322.73$ & 324.54 & $\$ 0.00$ & $\$ 2,692.93$ \\
Public infrastructure stock index & 252 & 22.11187 & 6.430653 & 9.138739 & 38.75019 \\
Share of manufacturing employment & 252 & 0.2743205 & 0.1481094 & 0.0388917 & 0.6566179 \\
Domestic market potential. Thousands (MXN) & 252 & $\$ 50,800,000.00$ & $7.16 \mathrm{E}+07$ & $\$ 1,105,058.00$ & $\$ 515,000,000.00$ \\
US market potential (USD millions) & 252 & $\$ 25,205.38$ & 87712.28 & $\$ 127.96$ & $\$ 755,095.40$ \\
Market size (Total Gross Product). Thousands (MXN) & 252 & $\$ 45,300,000.00$ & $7.12 \mathrm{E}+07$ & $\$ 289,972.60$ & $\$ 511,000,000.00$ \\
Gcompetition EF\&S. Thousands (MXN) & 252 & $-\$ 0.87$ & $2.67 \mathrm{E}+00$ & $-\$ 6.69$ & $\$ 15.17$ \\
Gcompetition PII. Thousands (MXN) & 252 & $-\$ 0.09$ & $6.33 \mathrm{E}+00$ & $-\$ 10.55$ & $\$ 42.21$ \\
Scompetition EF\&S. Thousands (MXN) & 252 & $-\$ 0.30$ & $3.66 \mathrm{E}+00$ & $-\$ 6.09$ & $\$ 31.54$ \\
Scompetition PII. Thousands (MXN) & 252 & $\$ 0.01$ & $8.73 \mathrm{E}+00$ & $-\$ 17.39$ & $\$ 66.07$ \\
\hline
\end{tabular}

\section{Results}

\subsection{General Results 1993-2008.}

First, the baseline equation was estimated for all the municipalities form year 1993 to 2008. In table 2 the results of the baseline equation are presented using the different estimation methods. In column (1) pooled OLS are reported, FE with White standard errors are in column (2), column (3) presents Driscoll and Kraay, and difference GMM estimator with forward orthogonal transformation is in column (4). All models have been estimated using year dummies, and the standard errors are clusted by city/regional unit.

Pooled OLS tend to be less efficient given the higher number of constraints imposed to the estimation. Standard errors are bigger and coefficients might be biased due to the need of controlling for FE. It can be seen that the pooled OLS results are not consistent with the expected sign of all variables, and showed significant differences for infant mortality rate, market potential and market size variables. The FE model is more consistent, which confirms that it is better to add within FE when addressing regions. Using FE with Driscoll and Kraay method, coefficients and signs remain the same, yet the model is more efficient as the standard errors are smaller.

In column (4) with difference GMM method the sign of the variables are the same and the coefficients are slightly lower, which confirms consistency in the model results. In this estimation, it is expected to reject autocorrelation in first order, but no in second order. This is confirmed by the tests shown at the end of the table. Hansen statistic indicates that the instruments used for the potential endogenous variables are valid, which used up to the second lag of the variables using collapse option to avoid proliferation of instruments as it decreases efficiency in the model.

Following Bond et al. [18] and Roodman [19] the suspected not strictly exogenous variables were instrumented using the option collapse to prevent too many instruments. The Hansen J statististic and the Sargan tests confirmed that the instruments were valid. Now, if the coefficients of the instrumented variables are similar to the FE estimations, it means that endogeneity is not an issue [18]. Particularly, the interest variables showed similar coefficients with GMM and with Driscoll and Kraay FE methods, confirming that endogenity is not biasing the results. On the other hand, when using DK standard errors to control for cross-section dependence the model is more efficient. Also, considering the previously mentioned advantages of this method to this particular data set, DK method is chosen above the others.

It should remarked that most regional policies are expected to influence on private investment decisions with some years lags, rather than on the same year. Hence, using lags of the expenditure variables instead of the contemporaneous data might be more adequate. Accordingly, the baseline equation has been re-estimated with the different methods but using the third lag of the interest variables, instead of the contemporaneous data. This is shown in the table 3 .

Most variables do not change their sign and their coefficients vary slightly compared to the results in table 2 . However, the sign of PII has changed. It makes sense, since this is investment in public infrastructure, which effects over investment decisions are more likely to be revealed in the mid and long terms. It is worrisome that the effect shows to be negative, while it was expected to have positive influence on private investors, however.

As regards with the validity of the models, the results are similar to the previous table. Pooled OLS method seems less efficient than the others, and the sign of variables such 
as infant mortality rate, market size, and industrial employment share are the opposite, compared to the other methods. Meanwhile, FE with White standard errors, DK and difference GMM estimation results are consistent. The variables' coefficients for FE, DK and difference GMM methods are slightly different, and sometimes the same. The interest variables are very close to the FE results and the Hansen test showed the instruments to be valid. In view of that, it can be said that endogeneity is not a problem in the model, since very similar results are obtained with the three methods, yet DK is the most efficient. The difference in signs of the variable PII per employee can be identified as the effect over the time or within the mid-term.

In these baseline results, is shown that governments' expenditures on PII are slightly more important than those on EF\&S. Nevertheless, the former might have negative influence on private investment decisions. This can be related to the type of projects and public works done at the local level in Mexico. Namely, the municipality contribute with public works on parks, drainage, urban roads, water feeds, general cleaning and other local infrastructure that is not directly linked to firms' needs, but with general services and wellbeing. The coefficient indicates that for every $10 \%$ increase on PII per employee undertaken in t-3 year, there has been $0.59 \%$ decrease on new private investment with respect to the previous year of the Economic Census. Likewise, for $10 \%$ increase on EF\&S per employee in $\mathrm{t}-3$ year, there has been $0.4 \%$ increments in new private investment with respect to the previous year.

Market potential is the most important driver for investment, and there are decreasing returns to the level of total TGP, as expected. Public stock of infrastructure has been confirmed as a significant driver for private investment, which should have been reinforced by the local expenditures on PII, yet several reasons might explain the opposite sign of the variable. First, it should be taken into account that infrastructure stock regards with the actual assets available in the city, while PII is the expenditure item. Expenditures on infrastructure are frequently an easy source of resources, thus corruption might be involved causing high expenditures but few physical assets [28].

In addition, the assets may be more costly in some places than in others given the geography or other natural conditions. Other public infrastructure projects from state and federal government might be more influential for investment decisions.

Given that variable for infrastructure is an index which annual value depend on the other cities' endowments, the coefficient is hard to interpret in absolute terms. Still, it is clear that more public infrastructure stock influences positively the new private investment. In this case $10 \%$ increase in the index, induced $0.45 \%$ increments on private investment during the period 1993-2008.

Table 2. Results including all firms, 1993-2008

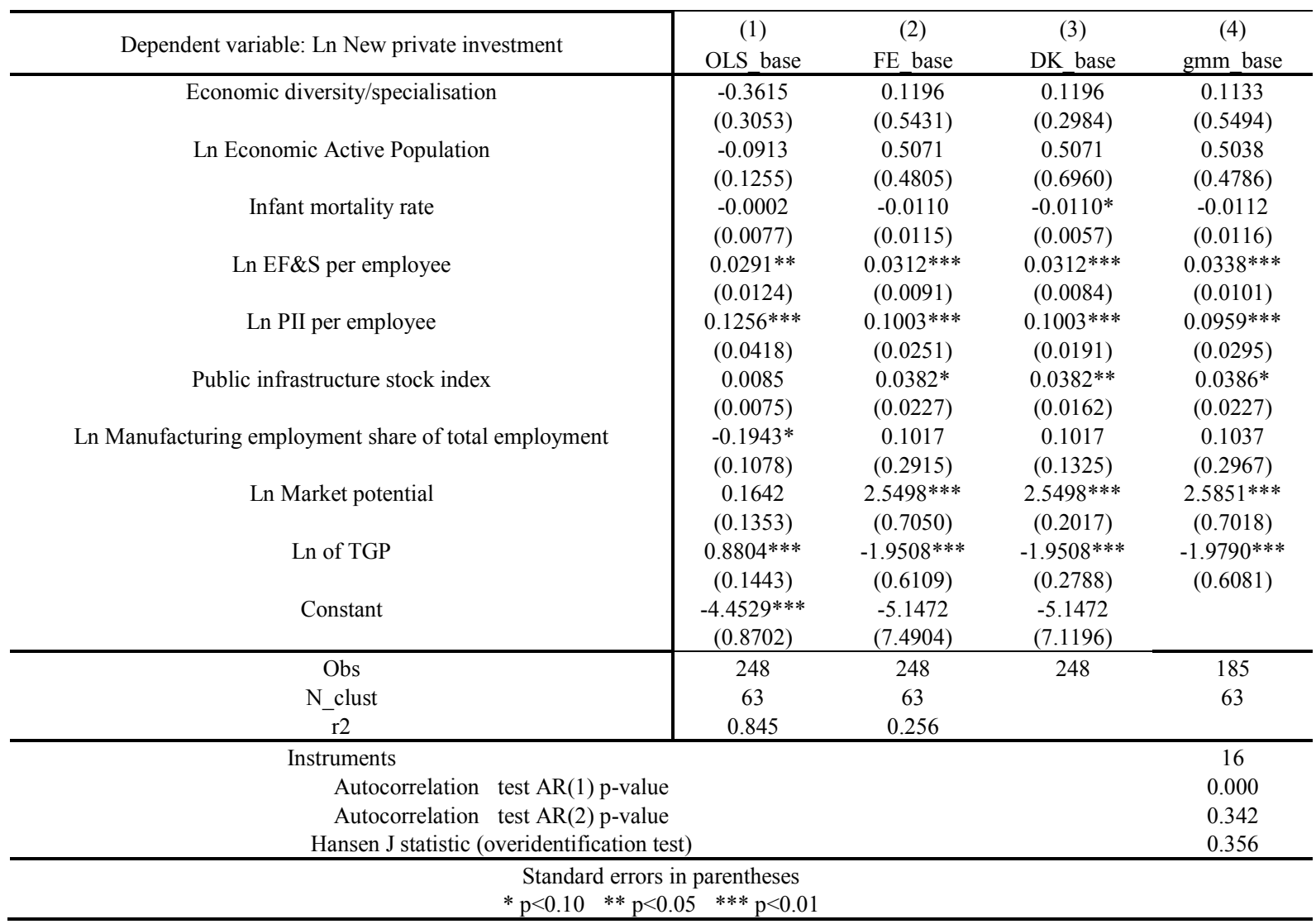


Infant mortality rate showed the expected sign but it is not statistically significant, neither the rest of the variables, namely Economic Active Population, Economic specialisation index and share of employment on manufacturing activities. Infant mortality rate was statistically significant in the previous results on table 2, with a higher coefficient. This might indicate that its true value is larger.

Table 3. Baseline results including all firms. Using lags of interest variables.

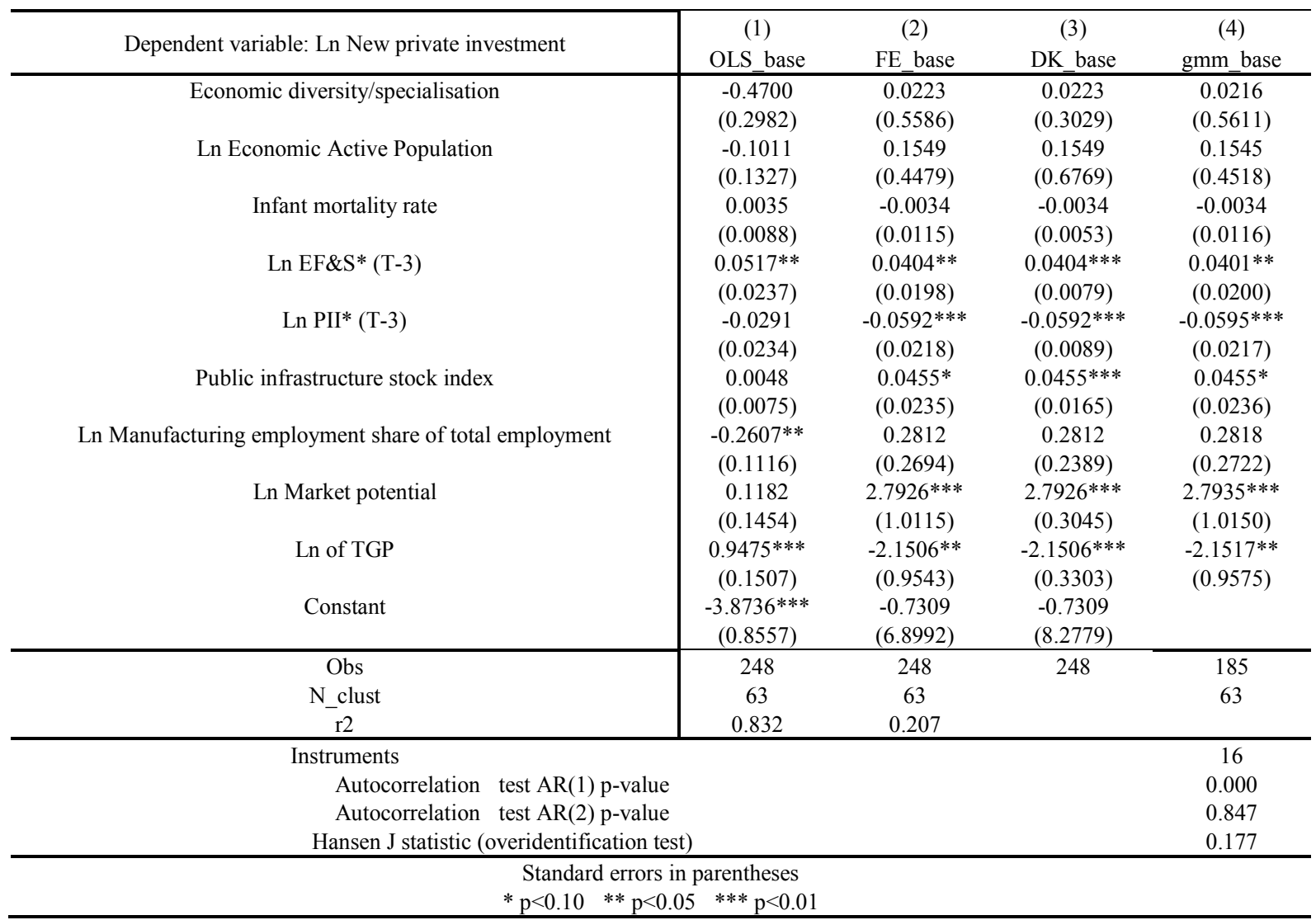

Once it has been established the best estimation method, the entire set of variables proposed are added to the baseline results, see table 4. For comparison purposes the baseline results are in column (1), the competition variables are in columns (2) and (3) and the interaction terms in columns (4) and (5). The additional variables are expressed in levels and not in logarithms. From the results, it is clear that Gcompetition is more important than Scompetition. It means that spending more money on EF\&S and PII than geographically close cities can lead to larger growth of private investment. As expected, this indicate that cities have to compete first against cities within the same state or region. Capital cities in the states tend to get more political support and financial resources, making that competition within the same state might be the most important for Mexican cities. Although dummies for political capitals are not included, given the size of the panel.

The coefficient for GcompetitionPII is 0.0371 and for GcompetitionEF\&S is 0.0417 , it means that a sum of $\$ 100.00 \mathrm{MXN}$ is related to approximately $0.37 \%$ and $0.42 \%$ larger new private investment, respectively. For instance, there are at least 10 cities which had more than $\$ 1,000.00$ MXN in either variables, which could entail influence on private investment to a good extent by this mean. The size of Scompetition variables are much smaller. The ScompetitionPII coefficient indicates that a city is spending a total of $\$ 100$ MXN more than its close competitors on PII is related to higher new private investment of $0.16 \%$, while ScompetitionEF\&S is not significant.

Considering that the yearly growth rates of private investment are also small, the effects of competition should not be neglected, especially if major spending might represent more decentralised funds boosting investments.

The interaction terms in columns (3) and (4) are statistically significant. Nonetheless, manufacturing employment is not significant in any case, the additional effect is very small, and given that the coefficient of the interest variables become a bit smaller when introducing the interaction term; it cannot be concluded that there are additional effects of such expenditures consistent to the level of manufacturing employment in the city. 
Table 4. Alternative results including all firms with Driscoll and Kraay method.

\begin{tabular}{|c|c|c|c|c|c|}
\hline Dependent variable: Ln New private investment & $\begin{array}{c}\text { (1) } \\
\text { DK_base }\end{array}$ & $\begin{array}{c}(2) \\
\text { Gcomp }\end{array}$ & $\begin{array}{c}(3) \\
\text { Scomp }\end{array}$ & $\begin{array}{c}(4) \\
\text { Ind*EF\&S }\end{array}$ & $\begin{array}{c}(5) \\
\text { Ind*PIII } \\
\end{array}$ \\
\hline Economic diversity/specialisation & $\begin{array}{c}0.0223 \\
(0.3029)\end{array}$ & $\begin{array}{c}0.3928 \\
(0.4433)\end{array}$ & $\begin{array}{c}0.1215 \\
(0.3232)\end{array}$ & $\begin{array}{c}0.0195 \\
(0.3183)\end{array}$ & $\begin{array}{c}0.2397 \\
(0.3612)\end{array}$ \\
\hline Ln Economic Active Population & $\begin{array}{c}0.1549 \\
(0.6769)\end{array}$ & $\begin{array}{l}0.9018^{*} \\
(0.5030)\end{array}$ & $\begin{array}{c}0.3870 \\
(0.6889)\end{array}$ & $\begin{array}{c}0.1791 \\
(0.6860)\end{array}$ & $\begin{array}{c}0.3406 \\
(0.7030)\end{array}$ \\
\hline Infant mortality rate & $\begin{array}{c}-0.0034 \\
(0.0053)\end{array}$ & $\begin{array}{l}-0.0079 \\
(0.0057)\end{array}$ & $\begin{array}{l}-0.0046 \\
(0.0054)\end{array}$ & $\begin{array}{l}-0.0057 \\
(0.0051)\end{array}$ & $\begin{array}{l}-0.0038 \\
(0.0062)\end{array}$ \\
\hline Ln EF\&S (T-3)* & $\begin{array}{c}0.0404 * * * \\
(0.0079)\end{array}$ & $\begin{array}{c}0.0411 * * * \\
(0.0071)\end{array}$ & $\begin{array}{c}0.0362 * * * \\
(0.0077)\end{array}$ & $\begin{array}{c}0.0381 * * * \\
(0.0087)\end{array}$ & $\begin{array}{c}0.0395 * * * \\
(0.0069)\end{array}$ \\
\hline Ln PII $(\mathrm{T}-3)^{*}$ & $\begin{array}{c}-0.0592 * * * \\
(0.0089)\end{array}$ & $\begin{array}{c}-0.0577 * * * \\
(0.0098)\end{array}$ & $\begin{array}{c}-0.0579 * * * \\
(0.0076)\end{array}$ & $\begin{array}{c}-0.0775 * * * \\
(0.0133)\end{array}$ & $\begin{array}{c}-0.0479 * * * \\
(0.0159)\end{array}$ \\
\hline Public infrastructure stock index & $\begin{array}{c}0.0455^{* * *} \\
(0.0165)\end{array}$ & $\begin{array}{c}0.0385^{* * *} * \\
(0.0112)\end{array}$ & $\begin{array}{c}0.0422 * * * \\
(0.0139)\end{array}$ & $\begin{array}{c}0.0426 * * \\
(0.0168)\end{array}$ & $\begin{array}{c}0.0400 * * * \\
(0.0139)\end{array}$ \\
\hline Ln Manufacturing employment share of total employment & $\begin{array}{c}0.2812 \\
(0.2389)\end{array}$ & $\begin{array}{c}0.1966 * * \\
(0.0931)\end{array}$ & $\begin{array}{c}0.2999 \\
(0.1818)\end{array}$ & $\begin{array}{c}0.2076 \\
(0.2215)\end{array}$ & $\begin{array}{c}0.1354 \\
(0.2161)\end{array}$ \\
\hline Ln Market potential & $\begin{array}{c}2.7926 * * * \\
(0.3045)\end{array}$ & $\begin{array}{c}2.2445 * * * \\
(0.3214)\end{array}$ & $\begin{array}{c}2.4627 * * * \\
(0.4384)\end{array}$ & $\begin{array}{c}2.9154 * * * \\
(0.2878)\end{array}$ & $\begin{array}{c}2.4800 * * * \\
(0.3029)\end{array}$ \\
\hline Ln of TGP & $\begin{array}{c}-2.1506 * * * \\
(0.3303)\end{array}$ & $\begin{array}{c}-1.7081 * * * \\
(0.2743)\end{array}$ & $\begin{array}{c}-1.9444 * * * \\
(0.4509)\end{array}$ & $\begin{array}{c}-2.2726^{* * * *} \\
(0.3306)\end{array}$ & $\begin{array}{c}-1.9000 * * * \\
(0.3054)\end{array}$ \\
\hline Geographic competition EF\&S(T-3)* & & $\begin{array}{c}0.0417 * * * \\
(0.0080)\end{array}$ & & & \\
\hline Geographic competition PIII(T-3)* & & $\begin{array}{c}0.0371 * * * \\
(0.0062)\end{array}$ & & & \\
\hline Competition by economic specialisation EF\&S(T-3)* & & & $\begin{array}{c}0.0051 \\
(0.0043)\end{array}$ & & \\
\hline Competition by economic specialisation PIII(T-3)* & & & $\begin{array}{c}0.0163 * * * \\
(0.0048)\end{array}$ & & \\
\hline Manufacturing employment share $\times \mathrm{EF} \& \mathrm{~S}(\mathrm{~T}-3)^{*}$ & & & & $\begin{array}{c}0.0020 * * \\
(0.0010)\end{array}$ & \\
\hline Manufacturing employment share $\times \mathrm{PII}(\mathrm{T}-3)^{*}$ & & & & & $\begin{array}{c}0.0015 * * * \\
(0.0004)\end{array}$ \\
\hline Constant & $\begin{array}{r}-0.7309 \\
(8.2779) \\
\end{array}$ & $\begin{array}{c}-8.2425 \\
(5.8672) \\
\end{array}$ & $\begin{array}{l}-1.3840 \\
(8.1417) \\
\end{array}$ & $\begin{array}{c}-1.0737 \\
(8.1627) \\
\end{array}$ & $\begin{array}{c}-2.3284 \\
(8.4161) \\
\end{array}$ \\
\hline Obs & 248 & 248 & 248 & 248 & 248 \\
\hline \multicolumn{6}{|c|}{ Standard errors in parentheses } \\
\hline
\end{tabular}

\subsection{Manufacturing Firms 1993-2008.}

The following table 5 presents the results for all manufacturing firms -foreign and domestic- from 1993 to 2008. The baseline results in column (1) present various differences with the total results on table 4 . The interest variables remained with the same sign but smaller coefficients than those for the total firms. In any case, the elasticity is less than $1 \%$. In the base equation in column (1), for $10 \%$ increase on EF\&S expenditures in the year $\mathrm{t}-3$, there was an increment of $0.32 \%$ on new private investment, while for $10 \%$ increase of PII in the year $\mathrm{t}-3$, there was a decrease of $0.39 \%$ on new private investment. It would have been expected that manufacturing firms were more influenced by the EF\&S investment, since many cities aim to encourage the manufacturing sector, but the coefficient is about the same. Still, the negative effect of PII is smaller than for the total firms, which indicate that some manufacturing firms might be positively influenced.

Most of the variables sign remained the same, except for Economic diversity/specialisation index which sign changed. Yet, the variable is not significant in any case, and no conclusion can be drawn. The infant mortality rate has a negative sign, its coefficient is larger, and it is statistically significant similarly to the results in table 3 .

There are two findings important to remark. First, the share of the manufacturing employment is significant in these estimations, which is related to the role played by other manufacturing firms in the city, and of course it is also linked to the same firms that are re-investing in the city. Second, the coefficient of public infrastructure index is about $60 \%$ larger for manufacturing firms, which regards with the nature of such firms that benefit more from the available public infrastructure.

Competition variables in columns (2) and (3), suggest that spending more than the geographically close cities is more important than spending more than cities with similar economic specialisation. Both coefficients are a bit smaller compared to the total firms, which is also in line with the main interest variables coefficients (EF\&S and PII). According to their coefficients if the sum of the expenditures on EF\&S and PII in the year ( $\mathrm{t}-3)$ is $\$ 100.00$ MXN higher than the regional competitors the city had $0.32 \%$ and $0.28 \%$ more new private investment, respectively. As for ScompetitionPII, the coefficient indicated that a city spending $\$ 100.00 \mathrm{MXN}$ than cities with similar economic specialisation on year $(\mathrm{t}-3)$ had $0.14 \%$ more private investment. 
Table 5. Results including only manufacturing firms, 1993-2008, using Driscoll and Kraay method.

\begin{tabular}{|c|c|c|c|c|c|}
\hline Dependent variable: Ln New private investment & $\begin{array}{c}(1) \\
\text { DK base }\end{array}$ & $\begin{array}{c}(2) \\
\text { Gcomp }\end{array}$ & $\begin{array}{c}(3) \\
\text { Scomp }\end{array}$ & $\begin{array}{c}(4) \\
\text { Ind*EF\&S }\end{array}$ & $\begin{array}{c}(5) \\
\text { Ind*PIII }\end{array}$ \\
\hline Economic diversity/specialisation & $\begin{array}{c}-0.2192 \\
(0.1811)\end{array}$ & $\begin{array}{c}-0.0056 \\
(0.2855)\end{array}$ & $\begin{array}{c}-0.1699 \\
(0.1765)\end{array}$ & $\begin{array}{c}-0.2723 \\
(0.2036)\end{array}$ & $\begin{array}{c}-0.0001 \\
(0.2391)\end{array}$ \\
\hline Ln Economic Active Population & $\begin{array}{c}0.1541 \\
(0.5688)\end{array}$ & $\begin{array}{c}0.7287 \\
(0.5852)\end{array}$ & $\begin{array}{c}0.3494 \\
(0.6298)\end{array}$ & $\begin{array}{c}0.1763 \\
(0.5841)\end{array}$ & $\begin{array}{c}0.3378 \\
(0.6239)\end{array}$ \\
\hline Infant mortality rate & $\begin{array}{c}-0.0120 * * * \\
(0.0034)\end{array}$ & $\begin{array}{c}-0.0154 * * * \\
(0.0031)\end{array}$ & $\begin{array}{c}-0.0111 * * * \\
(0.0035)\end{array}$ & $\begin{array}{c}-0.0138 * * * \\
(0.0037)\end{array}$ & $\begin{array}{c}-0.0125^{* * *} * \\
(0.0036)\end{array}$ \\
\hline Ln EF\&S (T-3)* & $\begin{array}{l}0.0317^{*} \\
(0.0180)\end{array}$ & $\begin{array}{l}0.0336^{*} \\
(0.0177)\end{array}$ & $\begin{array}{l}0.0299^{*} \\
(0.0172)\end{array}$ & $\begin{array}{c}0.0308 \\
(0.0190)\end{array}$ & $\begin{array}{l}0.0309^{*} \\
(0.0163)\end{array}$ \\
\hline Ln PII (T-3)* & $\begin{array}{c}-0.0392 * * * \\
(0.0039)\end{array}$ & $\begin{array}{c}-0.0324 * * * \\
(0.0055)\end{array}$ & $\begin{array}{c}-0.0284 * * * \\
(0.0041)\end{array}$ & $\begin{array}{c}-0.0505 * * * \\
(0.0136)\end{array}$ & $\begin{array}{c}-0.0283 * * * * \\
(0.0076)\end{array}$ \\
\hline Public infrastructure stock index & $\begin{array}{c}0.0734 * * \\
(0.0317)\end{array}$ & $\begin{array}{c}0.0708 * * \\
(0.0340)\end{array}$ & $\begin{array}{c}0.0735^{* *} \\
(0.0349)\end{array}$ & $\begin{array}{c}0.0728 * * \\
(0.0308)\end{array}$ & $\begin{array}{l}0.0682^{*} \\
(0.0357)\end{array}$ \\
\hline Ln Manufacturing employment share of total employment & $\begin{array}{c}0.9153 * * * \\
(0.1217)\end{array}$ & $\begin{array}{c}0.8679 * * * \\
(0.0267)\end{array}$ & $\begin{array}{c}0.9318 * * * \\
(0.0966)\end{array}$ & $\begin{array}{c}0.8735 * * * \\
(0.1114)\end{array}$ & $\begin{array}{c}0.7636^{* * * *} \\
(0.0930)\end{array}$ \\
\hline Ln Market potential & $\begin{array}{c}2.3876 * * * \\
(0.6092)\end{array}$ & $\begin{array}{c}1.9416 * * * \\
(0.5517)\end{array}$ & $\begin{array}{c}2.0546 * * * \\
(0.7241)\end{array}$ & $\begin{array}{c}2.4695 * * * \\
(0.6400)\end{array}$ & $\begin{array}{c}2.0805 * * * \\
(0.5963)\end{array}$ \\
\hline Ln of TGP & $\begin{array}{c}-1.6091 * * \\
(0.6414)\end{array}$ & $\begin{array}{c}-1.2131 * * \\
(0.5483)\end{array}$ & $\begin{array}{c}-1.3516^{*} \\
(0.7456)\end{array}$ & $\begin{array}{c}-1.6681 * * \\
(0.6749)\end{array}$ & $\begin{array}{c}-1.3643 * * \\
(0.6151)\end{array}$ \\
\hline Geographic competition EF\&S(T-3)* & & $\begin{array}{l}0.0321^{*} \\
(0.0178)\end{array}$ & & & \\
\hline Geographic competition PIII(T-3)* & & $\begin{array}{c}0.0283 * * * \\
(0.0085)\end{array}$ & & & \\
\hline Competition by economic specialisation EF\&S(T-3)* & & & $\begin{array}{c}-0.0086 \\
(0.0075)\end{array}$ & & \\
\hline Competition by economic specialisation PIII(T-3)* & & & $\begin{array}{c}0.0141 * * * \\
(0.0042)\end{array}$ & & \\
\hline Manufacturing employment share $\times \mathrm{EF} \& \mathrm{~S}(\mathrm{~T}-3)^{*}$ & & & & $\begin{array}{c}0.0017 \\
(0.0015)\end{array}$ & \\
\hline Manufacturing employment share $\times \mathrm{PII}(\mathrm{T}-3)^{*}$ & & & & & $\begin{array}{c}0.0015 * * * \\
(0.0004)\end{array}$ \\
\hline Constant & $\begin{array}{l}-3.5382 \\
(7.2932)\end{array}$ & $\begin{array}{l}-9.8636 \\
(6.3251)\end{array}$ & $\begin{array}{c}-4.6820 \\
(7.5923)\end{array}$ & $\begin{array}{c}-4.2249 \\
(7.4046)\end{array}$ & $\begin{array}{l}-5.1237 \\
(7.5267)\end{array}$ \\
\hline Obs & 246 & 246 & 246 & 246 & 246 \\
\hline \multicolumn{6}{|c|}{$\begin{array}{l}\text { Standard errors in parentheses } \\
* \mathrm{p}<0.10 \quad * * \mathrm{p}<0.05 \quad * * * \mathrm{p}<0.01\end{array}$} \\
\hline
\end{tabular}

The models with the interaction terms in columns (4) and (5) showed that, in the case of EF\&S, the additional effect given the level of manufacturing employments is not significant, while the interaction term with PII is statistically significant. Considering that the individual effect of the variable PII is negative, the positive sign of the interaction term could indicate that cities with higher shares of manufacturing employment might have lesser negative effects of the total expenditures on PII. Additionally, the individual effect of the variable is bigger from -0.0392 in column (1) to -0.0283 in column (5). The coefficient of the interaction term indicate that, for instance, if a city share of manufacturing employment is 0.5 , by every $\$ 10.00$ MXN expenditures on PII per employee there is an additional increase of $0.75 \%$ of new private investment, which is added to the individual effect. In this case they cannot be added directly given that PII coefficient is presented in natural logarithms.

\subsection{Domestic Firms Results 1998-2008}

In table 6 , results for all domestic firms are presented. In column (1) the baseline results are considerably different than those shown in table 3 . The interest variables have changed their sign, indicating different effects of public expenditures across domestic/foreign-joint venture firms. It seems that in average, the public expenditures on EF\&S have had a negative effect over domestic investment, although the size of the coefficient is small, $10 \%$ increase on EF\&S per employee in the year (t-3), is related to only $0.21 \%$ decrease in new private investment. Still this is worrisome given that most of the attention received by domestic firms comes from municipal governments, and this results indicate that their actions are not encouraging private investment, as they should. The variable PII is not statistically significant. This again indicates little effect of these outlays on private investment growth.

The economic diversity/specialisation index is significant and its coefficient is larger. In other words, domestic private investment growth rates are higher when the city is more specialised. The public infrastructure stock index is negatively correlated to the new private investment, as well as the share of manufacturing employment in the city and the total TGP. Infant mortality rate did not show the expected sign. Given that it had the correct sign for total results, and for foreign firms, this could indicate that domestic firms' investment growth is not highly influenced by the local health and wellbeing; while this is more important for foreign investors, as it will be confirmed by the respective estimations. 
Table 6. Results including only domestic firms 1998-2008, total. Using Driscoll and Kraay method.

\begin{tabular}{|c|c|c|c|c|c|}
\hline Dependent variable: Ln New private investment & $\begin{array}{c}(1) \\
\text { base }\end{array}$ & $\begin{array}{c}(2) \\
\text { Gcomp }\end{array}$ & $\begin{array}{c}(3) \\
\text { Scomp } \\
\end{array}$ & $\begin{array}{c}(4) \\
\text { Ind*EF\&S }\end{array}$ & $\begin{array}{c}(5) \\
\text { Ind*PII }\end{array}$ \\
\hline Economic diversity/specialisation & $\begin{array}{c}0.4949^{*} \\
(0.2670)\end{array}$ & $\begin{array}{c}0.4473^{* *} \\
(0.2140)\end{array}$ & $\begin{array}{c}0.4070 \\
(0.3130)\end{array}$ & $\begin{array}{l}0.4591 * \\
(0.2448)\end{array}$ & $\begin{array}{c}0.4649^{*} \\
(0.2616)\end{array}$ \\
\hline Ln Economic Active Population & $\begin{array}{c}1.6927 * * * \\
(0.1059)\end{array}$ & $\begin{array}{c}1.7516 * * * \\
(0.0076)\end{array}$ & $\begin{array}{c}1.8003 * * * \\
(0.0668)\end{array}$ & $\begin{array}{c}1.6914 * * * \\
(0.1266)\end{array}$ & $\begin{array}{c}1.8301 * * * \\
(0.0380)\end{array}$ \\
\hline Infant mortality rate & $\begin{array}{c}0.0271 * * \\
(0.0122)\end{array}$ & $\begin{array}{c}0.0254^{*} \\
(0.0127)\end{array}$ & $\begin{array}{c}0.0256^{*} \\
(0.0129)\end{array}$ & $\begin{array}{c}0.0253^{*} \\
(0.0128)\end{array}$ & $\begin{array}{c}0.0278^{* *} \\
(0.0121)\end{array}$ \\
\hline Ln EF\&S (T-3)* & $\begin{array}{c}-0.0205^{* * *} \\
(0.0058)\end{array}$ & $\begin{array}{c}-0.0181 * * * \\
(0.0047)\end{array}$ & $\begin{array}{c}-0.0202 * * * \\
(0.0047)\end{array}$ & $\begin{array}{c}-0.0213 * * * \\
(0.0055)\end{array}$ & $\begin{array}{c}-0.0164 * * * \\
(0.0049)\end{array}$ \\
\hline Ln PII (T-3)* & $\begin{array}{l}-0.0010 \\
(0.0145)\end{array}$ & $\begin{array}{c}0.0009 \\
(0.0111)\end{array}$ & $\begin{array}{c}-0.0056 \\
(0.0134)\end{array}$ & $\begin{array}{l}-0.0128 \\
(0.0229)\end{array}$ & $\begin{array}{c}0.0057 \\
(0.0119)\end{array}$ \\
\hline Public infrastructure stock index & $\begin{array}{l}-0.0206^{*} \\
(0.0107)\end{array}$ & $\begin{array}{c}-0.0207 * * \\
(0.0101)\end{array}$ & $\begin{array}{c}-0.0216^{* *} \\
(0.0102)\end{array}$ & $\begin{array}{c}-0.0215^{* *} \\
(0.0098)\end{array}$ & $\begin{array}{c}-0.0198^{*} \\
(0.0116)\end{array}$ \\
\hline $\begin{array}{l}\text { Ln Manufacturing employment share of total } \\
\text { employment }\end{array}$ & $\begin{array}{c}-0.8973 * * * \\
(0.3113)\end{array}$ & $\begin{array}{c}-0.8180 * * \\
(0.3411)\end{array}$ & $\begin{array}{c}-0.8160 * * \\
(0.3555)\end{array}$ & $\begin{array}{c}-0.8951 * * * \\
(0.3021)\end{array}$ & $\begin{array}{c}-0.9088 * * * \\
(0.3157)\end{array}$ \\
\hline Ln Market potential & $\begin{array}{c}0.8445^{* * *} \\
(0.2058)\end{array}$ & $\begin{array}{l}0.6822 * * * \\
(0.1508)\end{array}$ & $\begin{array}{c}0.8206^{* * *} \\
(0.1415)\end{array}$ & $\begin{array}{c}0.9012 * * * \\
(0.1599)\end{array}$ & $\begin{array}{c}0.6956^{* * *} \\
(0.1506)\end{array}$ \\
\hline Ln of TGP & $\begin{array}{l}-0.7454 * * * \\
(0.2459)\end{array}$ & $\begin{array}{c}-0.6292^{* *} \\
(0.2623)\end{array}$ & $\begin{array}{c}-0.7854 * * * \\
(0.2089)\end{array}$ & $\begin{array}{c}-0.8028 * * * \\
(0.1706)\end{array}$ & $\begin{array}{c}-0.6475^{* *} \\
(0.2692)\end{array}$ \\
\hline $\begin{array}{l}\text { Geographic competition EF\&S(T-3)* } \\
\text { Geographic competition PII(T-3)* }\end{array}$ & & $\begin{array}{l}0.0110 \\
(0.0170) \\
0.0132 * \\
(0.0079)\end{array}$ & & & \\
\hline $\begin{array}{l}\text { Competition by economic specialisation EF\&S(T-3)* } \\
\text { Competition by economic specialisation PII(T-3)* }\end{array}$ & & & $\begin{array}{c}0.0080 \\
(0.0079) \\
0.0057 \\
(0.0077)\end{array}$ & & \\
\hline Manufacturing employment share $\times \mathrm{EF} \& \mathrm{~S}(\mathrm{~T}-3)^{*}$ & & & & $\begin{array}{c}0.0012 \\
(0.0014)\end{array}$ & \\
\hline Manufacturing employment share $\times \mathrm{PII}(\mathrm{T}-3)^{*}$ & & & & & $\begin{array}{l}0.0008^{*} \\
(0.0005)\end{array}$ \\
\hline Constant & $\begin{array}{c}-10.5924 * * * \\
(2.3900) \\
\end{array}$ & $\begin{array}{c}-10.3551 * * * \\
(2.1923) \\
\end{array}$ & $\begin{array}{c}-10.6645^{* * *} \\
(2.4120) \\
\end{array}$ & $\begin{array}{c}-10.5263 * * * \\
(2.1814) \\
\end{array}$ & $\begin{array}{c}-11.5509^{* * *} \\
(2.9030)\end{array}$ \\
\hline Obs & 187 & 187 & 187 & 187 & 187 \\
\hline \multicolumn{6}{|c|}{ ndard errors in parentheses } \\
\hline
\end{tabular}

In sum, according to these results, the domestic private investment is positively influenced only by the potential market, the availability of labour force -EAP- and the higher economic specialisation of the cities. Whereas the local public policies to foster private investment, particularly EF\&S, showed negative relation to domestic investment and the PII showed null influence.

From those results, it can be expected that the competition variables and the interaction terms have null or little effect over new private investment. In column (2) and (3) only GcompetitionPII is statistically significant with a coefficient of similar size to the previous results. Nevertheless, given the null effect of this variable on the baseline results, it cannot be asserted that competing by PII would have a great effect over firms' investments.

The interaction terms in columns (4) and (5), only the interaction term with PII is statistically significant. Nevertheless, due to the non-significance of PII, it is not possible to confirm additional effects of public expenditures given certain level of manufacturing employment.

\subsection{Joint Venture and Foreign Firms 1998-2008.}

For these estimations the number of observations are reduced given that there are some cities within the sample in which there are no foreign/joint venture firms. In column (1) it is clear that municipal expenditures on EF\&S and PII have had a significant effect over foreign firms. On the other side, PII expenditures showed a negative sign, and its coefficient is slightly larger than the EF\&S. In this way, raising the spending on EF\&S and PII by $10 \%$, is related to an increment of new private investment for $0.5 \%$ and a decrease for $0.53 \%$, respectively, which is indeed contradictory. 
Table 7. Results including only foreign and joint-venture firms 1998-2008, total. Using Driscoll and Kraay method.

\begin{tabular}{|c|c|c|c|c|c|}
\hline Dependent variable: Ln New private investment & $\begin{array}{c}(1) \\
\text { base }\end{array}$ & $\begin{array}{c}(2) \\
\text { Gcomp }\end{array}$ & $\begin{array}{c}(3) \\
\text { Scomp }\end{array}$ & $\begin{array}{c}\text { (4) } \\
\text { Ind*EF\&S }\end{array}$ & $\begin{array}{c}(5) \\
\text { Ind*PII }\end{array}$ \\
\hline Economic diversity/specialisation & $\begin{array}{c}0.2345 \\
(0.8365)\end{array}$ & $\begin{array}{c}0.4154 \\
(0.6083)\end{array}$ & $\begin{array}{c}0.2414 \\
(0.8385)\end{array}$ & $\begin{array}{c}0.0525 \\
(0.9059)\end{array}$ & $\begin{array}{c}0.2365 \\
(0.7835)\end{array}$ \\
\hline Ln Economic Active Population & $\begin{array}{c}-0.0000 \\
(0.0000)\end{array}$ & $\begin{array}{c}-0.0000 \\
(0.0000)\end{array}$ & $\begin{array}{l}-0.0000 \\
(0.0000)\end{array}$ & $\begin{array}{l}-0.0000^{*} \\
(0.0000)\end{array}$ & $\begin{array}{c}-0.0000 \\
(0.0000)\end{array}$ \\
\hline Infant mortality rate & $\begin{array}{l}-0.0090 \\
(0.0170)\end{array}$ & $\begin{array}{l}-0.0119 \\
(0.0173)\end{array}$ & $\begin{array}{l}-0.0092 \\
(0.0176)\end{array}$ & $\begin{array}{l}-0.0153 \\
(0.0150)\end{array}$ & $\begin{array}{l}-0.0097 \\
(0.0154)\end{array}$ \\
\hline Ln EF\&S(T-3)* & $\begin{array}{c}0.0491 * * * \\
(0.0005)\end{array}$ & $\begin{array}{c}0.0331 * * * \\
(0.0040)\end{array}$ & $\begin{array}{c}0.0462 * * * \\
(0.0030)\end{array}$ & $\begin{array}{c}0.0438 * * * \\
(0.0041)\end{array}$ & $\begin{array}{c}0.0540 * * * \\
(0.0015)\end{array}$ \\
\hline Ln PII(T-3)* & $\begin{array}{l}-0.0537 \\
(0.0344)\end{array}$ & $\begin{array}{c}-0.0694 * * \\
(0.0403)\end{array}$ & $\begin{array}{c}-0.0703^{*} \\
(0.0370)\end{array}$ & $\begin{array}{c}-0.1070 * * * \\
(0.0396)\end{array}$ & $\begin{array}{l}-0.0348 \\
(0.0412)\end{array}$ \\
\hline Public infrastructure stock index & $\begin{array}{c}0.0173 \\
(0.0142)\end{array}$ & $\begin{array}{c}0.0160 \\
(0.0162)\end{array}$ & $\begin{array}{c}0.0170 \\
(0.0142)\end{array}$ & $\begin{array}{c}0.0160 \\
(0.0135)\end{array}$ & $\begin{array}{c}0.0181 \\
(0.0144)\end{array}$ \\
\hline Ln Manufacturing employment share of total employment & $\begin{array}{l}-0.1843 \\
(1.0502)\end{array}$ & $\begin{array}{l}-0.2153 \\
(1.1233)\end{array}$ & $\begin{array}{c}-0.1422 \\
(1.0535)\end{array}$ & $\begin{array}{l}-0.0308 \\
(1.0258)\end{array}$ & $\begin{array}{l}-0.2525 \\
(1.0437)\end{array}$ \\
\hline Ln Market potential & $\begin{array}{c}1.4013 * * * \\
(0.2385)\end{array}$ & $\begin{array}{c}1.7101 * * * \\
(0.1606)\end{array}$ & $\begin{array}{c}1.4769 * * * \\
(0.2119)\end{array}$ & $\begin{array}{c}1.5837 * * * \\
(0.2117)\end{array}$ & $\begin{array}{c}1.3413 * * * \\
(0.2073)\end{array}$ \\
\hline Ln of TGP & $\begin{array}{c}-1.6889 * * * \\
(0.0867)\end{array}$ & $\begin{array}{c}-2.0454 * * * \\
(0.0955)\end{array}$ & $\begin{array}{c}-1.7877 * * * \\
(0.0804)\end{array}$ & $\begin{array}{c}-1.9123 * * * \\
(0.0607)\end{array}$ & $\begin{array}{c}-1.6617 * * * \\
(0.0904)\end{array}$ \\
\hline Ln US market potential & $\begin{array}{c}0.9475^{* * *} \\
(0.2339)\end{array}$ & $\begin{array}{c}0.9897 * * * \\
(0.2294)\end{array}$ & $\begin{array}{c}0.9726 * * * \\
(0.2641)\end{array}$ & $\begin{array}{c}1.0131 * * * \\
(0.2290)\end{array}$ & $\begin{array}{c}0.9609 * * * \\
(0.1991)\end{array}$ \\
\hline Geographic competition EF\&S(T-3)* & & $\begin{array}{c}0.1324 * * * \\
(0.0472)\end{array}$ & & & \\
\hline Geographic competition PII(T-3)* & & $\begin{array}{c}0.0111 * * * \\
(0.0092)\end{array}$ & & & \\
\hline Competition by economic specialisation EF\&S(T-3)* & & & $\begin{array}{c}-0.0589 * * \\
(0.0156)\end{array}$ & & \\
\hline Competition by economic specialisation PII(T-3)* & & & $\begin{array}{c}-0.3541^{* *} \\
(0.0043)\end{array}$ & & \\
\hline Manufacturing employment share $\times \mathrm{EF} \& \mathrm{~S}(\mathrm{~T}-3)^{*}$ & & & & $\begin{array}{c}0.0053 * * * \\
(0.0008)\end{array}$ & \\
\hline Manufacturing employment share $\times \mathrm{PII}(\mathrm{T}-3)^{*}$ & & & & & $\begin{array}{c}0.0016^{* * *} \\
(0.0003) \\
\end{array}$ \\
\hline Obs & 183 & 183 & 183 & 183 & 183 \\
\hline \multicolumn{6}{|c|}{ Standard errors in parentheses } \\
\hline
\end{tabular}

It was also found that the domestic market potential and the US market potential are the most significant drivers to foreign/joint-venture firms. Infant mortality rate showed a negative sign, yet not statistically significant, neither public infrastructure stock index, and the share of manufacturing employment. This is related to the type of firms mixed here. There are firms within financial services, tourism services and manufacturing, which depending on their final market public infrastructure might not influence to a great extent their investment decisions[30].

The competition variables added in columns (2) and (3) showed that those cities within the same geographic region spending more on EF\&S and PII have fostered foreign private investment. According to their coefficients if the sum of the expenditures on EF\&S and PII in the year (t-3) is $\$ 100.00 \mathrm{MXN}$ higher than the regional competitors, the city had $1.32 \%$ and $0.11 \%$ more new private investment, respectively. The size of the effect is in line with the effects of the individual variables, as EF\&S has larger and positive effects. In fact, this result tells that competition can significantly influence foreign investors. This is remarkable, because even if the resources are limited the estimations might indicate a race to the bottom which in fact ultimately damage the health of the local public finances [41]. On the contrary, investing more than cities with similar economic specialisation did not show a positive influence on private investment, similar to the previous results.

The interaction terms in columns (4) and (5) indicate that indeed, municipal expenditures can encourage more investment in cities with larger share of manufacturing employment. Namely, if the share of manufacturing employment is 0.27 -which is the mean of this variable-, then the additional effect of spending $\$ 10.00 \mathrm{MXN}$ per employee in EF\&S on year (t-3) would increase private investment in $0.41 \%$. Nevertheless, the interpretation of the total effect is not straightforward, since the manufacturing variable itself has a negative sign, and it is not statistically significant. Still, it can be said that municipal expenditures do have additional positive effects on new private investments from foreign/joint ventures depending on the level of manufacturing employment. Even for PII expenditures, since its coefficient is larger in column (5), meaning that its total effect is less negative or it could become even positive. 


\subsection{Domestic manufacturing firms 1998-2008.}

Table 8 shows the baseline results in column (1). The expenditures at the municipal level revealed negative effects over private investment, which is opposite to what should be expected, but in line with the previous results for domestic firms. As said before, local governments tend to provide support to domestic firms rather than to foreign ones, and in many cases their efforts are aimed to encourage manufacturing investment. Therefore, finding negative relationship is worrisome, since the policies are not hitting their goals. The coefficients indicate the for $10 \%$ increase on EF\&S and PII in the $(\mathrm{t}-3)$ year, there was a decrease of $0.67 \%$ and $0.49 \%$ in new private investment, respectively.

The share of manufacturing employment showed negative effect over private investment growth, which is only true when firms are divided into domestic and foreign firms. This might regard with competition. It is frequent that cities with high proportion of manufacturing firms have also wide presence of foreign investors. In such cases, domestic investors might be displaced as found by Aitken and Harrison [42]. Of course if domestic firms become suppliers and there are vertical spillovers, foreign investment may encourage domestic investment in manufacturing and boost productivity. Nevertheless, this is a process that can be very limited, as documented by Contreras et al [43].

Domestic market potential has been identified as the most important driver for investment, to a similar extent than the availability of labour force (Economic Active Population variable). It is remarkable that public infrastructure stock has a positive sign, opposite to the results when including all firms manufacturing in table 5 . In this way, it can be suspected that local projects of public infrastructure investments tend to be highly inefficient or do not bring immediate benefits for manufacturing firms. Namely, the expenditures do not show any positive influence, while the actual assets are positively linked to private investment. Additionally to inefficiencies or corruption ongoing, local projects could affect domestic firms if debt is used to undertake such investments, which do not affect foreign firms since they do not need financing support from local governments or the local financial system.

Table 8. Results including only domestic firms 1998-2008, manufacturing. Using Driscoll and Kraay method.

\begin{tabular}{|c|c|c|c|c|c|}
\hline Dependent variable: $\mathrm{Ln}$ New private investment & $\begin{array}{c}\text { (1) } \\
\text { base }\end{array}$ & $\begin{array}{c}(2) \\
\text { Gcomp }\end{array}$ & $\begin{array}{c}(3) \\
\text { Scomp }\end{array}$ & $\begin{array}{c}\text { (4) } \\
\text { Ind*EF\&S }\end{array}$ & $\begin{array}{c}(5) \\
\text { Ind*PII }\end{array}$ \\
\hline Economic diversity/specialisation & $\begin{array}{l}-0.3379 \\
(0.4304)\end{array}$ & $\begin{array}{l}-0.4151 \\
(0.3702)\end{array}$ & $\begin{array}{c}-0.3567 \\
(0.4525)\end{array}$ & $\begin{array}{l}-0.3847 \\
(0.4250)\end{array}$ & $\begin{array}{l}-0.3866 \\
(0.4025)\end{array}$ \\
\hline Ln Economic Active Population & $\begin{array}{l}1.3340 * * \\
(0.5842)\end{array}$ & $\begin{array}{l}1.3538 * * \\
(0.6710)\end{array}$ & $\begin{array}{l}1.5157^{*} \\
(0.9028)\end{array}$ & $\begin{array}{l}1.3289^{* *} \\
(0.5536)\end{array}$ & $\begin{array}{l}1.6458 * * \\
(0.6953)\end{array}$ \\
\hline Infant mortality rate & $\begin{array}{c}0.0071 \\
(0.0240)\end{array}$ & $\begin{array}{c}0.0030 \\
(0.0251)\end{array}$ & $\begin{array}{c}0.0115 \\
(0.0260)\end{array}$ & $\begin{array}{c}0.0035 \\
(0.0251)\end{array}$ & $\begin{array}{c}0.0090 \\
(0.0240)\end{array}$ \\
\hline Ln EF\&S (T-3)* & $\begin{array}{c}-0.0671 * * * \\
(0.0149)\end{array}$ & $\begin{array}{c}-0.0632 * * * \\
(0.0126)\end{array}$ & $\begin{array}{c}-0.0616 * * * \\
(0.0118)\end{array}$ & $\begin{array}{c}-0.0680 * * * \\
(0.0136)\end{array}$ & $\begin{array}{c}-0.0601 * * * \\
(0.0127)\end{array}$ \\
\hline Ln PII (T-3)* & $\begin{array}{c}-0.0481 * * * \\
(0.0170)\end{array}$ & $\begin{array}{c}-0.0541 * * \\
(0.0261)\end{array}$ & $\begin{array}{c}-0.0302 \\
(0.0188)\end{array}$ & $\begin{array}{c}-0.0666^{* *} \\
(0.0271)\end{array}$ & $\begin{array}{c}-0.0376 * * * \\
(0.0135)\end{array}$ \\
\hline Public infrastructure stock index & $\begin{array}{c}0.0971 * * * \\
(0.0260)\end{array}$ & $\begin{array}{c}0.0965 * * * \\
(0.0257)\end{array}$ & $\begin{array}{c}0.1027 * * * \\
(0.0271)\end{array}$ & $\begin{array}{c}0.0967 * * * \\
(0.0262)\end{array}$ & $\begin{array}{c}0.0997 * * * \\
(0.0280)\end{array}$ \\
\hline Ln Manufacturing employment share of total employment & $\begin{array}{c}-0.7675^{*} \\
(0.3873)\end{array}$ & $\begin{array}{c}-0.6516^{*} \\
(0.3637)\end{array}$ & $\begin{array}{l}-0.7486 \\
(0.4968)\end{array}$ & $\begin{array}{c}-0.7666^{* *} \\
(0.3729)\end{array}$ & $\begin{array}{l}-0.8019^{*} \\
(0.4017)\end{array}$ \\
\hline Ln Market potential & $\begin{array}{l}1.3560 * \\
(0.7747)\end{array}$ & $\begin{array}{c}1.0862 \\
(0.7052)\end{array}$ & $\begin{array}{l}1.1966^{*} \\
(0.7017)\end{array}$ & $\begin{array}{l}1.4203^{*} \\
(0.7490)\end{array}$ & $\begin{array}{c}1.0533 \\
(0.6594)\end{array}$ \\
\hline Ln of TGP & $\begin{array}{l}-0.2671 \\
(0.6586)\end{array}$ & $\begin{array}{l}-0.1220 \\
(0.6194)\end{array}$ & $\begin{array}{l}-0.1232 \\
(0.6394)\end{array}$ & $\begin{array}{l}-0.3644 \\
(0.6101)\end{array}$ & $\begin{array}{l}-0.0685 \\
(0.6479)\end{array}$ \\
\hline Geographic competition EF\&S(T-3)* & & $\begin{array}{c}0.0396 \\
(0.0271)\end{array}$ & & & \\
\hline Geographic competition PII(T-3)* & & $\begin{array}{c}0.0173 * * * \\
(0.0039)\end{array}$ & & & \\
\hline Competition by economic specialisation EF\&S(T-3)* & & & $\begin{array}{l}-0.0238 \\
(0.0214)\end{array}$ & & \\
\hline Competition by economic specialisation PII(T-3)* & & & $\begin{array}{c}0.0109 \\
(0.0125)\end{array}$ & & \\
\hline Manufacturing employment share $\times \mathrm{EF} \& \mathrm{~S}(\mathrm{~T}-3)^{*}$ & & & & $\begin{array}{c}0.0020 * * \\
(0.0009)\end{array}$ & \\
\hline Manufacturing employment share $\times \mathrm{PII}(\mathrm{T}-3)^{*}$ & & & & & $\begin{array}{c}0.0016^{* * *} \\
(0.0002)\end{array}$ \\
\hline Constant & $\begin{array}{c}-25.7846 * * \\
(12.1548)\end{array}$ & $\begin{array}{l}-23.5506^{*} \\
(12.5212)\end{array}$ & $\begin{array}{c}-27.9951 * * \\
(11.9801)\end{array}$ & $\begin{array}{c}-25.1238 * * \\
(11.5941)\end{array}$ & $\begin{array}{c}-28.1708 * * \\
(12.3057)\end{array}$ \\
\hline Obs & 178 & 178 & 178 & 178 & 178 \\
\hline \multicolumn{6}{|c|}{ Standard errors in parentheses } \\
\hline
\end{tabular}


The economic diversity/specialisation index changed its sign as well as the infant mortality rate, yet they are not statistically significant. From the competition variables in columns (2) and (3), only GcompetitionPII is significant. Even if the effect is positive, it is not enough to overpass the negative effect from the variable PII itself.

When adding the interaction terms in columns (4) and (5), both terms are statistically significant. Nevertheless, the expenditures variables -EF\&S and PII- and the share of manufacturing employment showed a negative effect over private investment. This shows that there might be lesser negative effects of local expenditures over investment whether the city has larger share of manufacturing employment. Nevertheless, the total effect could remain negative.

\subsection{Foreign/joint venture Manufacturing Firms 1998-2008.}

Table 9. Results including only foreign/joint-venture manufacturing firms 1998-2008. Using Driscoll and Kraay method.

\begin{tabular}{|c|c|c|c|c|c|}
\hline Dependent variable: Ln New private investment & $\begin{array}{c}\text { (1) } \\
\text { base } \\
\end{array}$ & $\begin{array}{c}(2) \\
\text { Gcomp }\end{array}$ & $\begin{array}{c}(3) \\
\text { Scomp } \\
\end{array}$ & $\begin{array}{c}(4) \\
\text { Ind*EF\&S }\end{array}$ & $\begin{array}{c}(5) \\
\text { Ind*PII }\end{array}$ \\
\hline Economic diversity/specialisation & $\begin{array}{c}0.6083 \\
(0.6708)\end{array}$ & $\begin{array}{c}0.3906 \\
(0.7624)\end{array}$ & $\begin{array}{c}0.5615 \\
(0.6760)\end{array}$ & $\begin{array}{c}0.6002 \\
(0.7050)\end{array}$ & $\begin{array}{c}0.5730 \\
(0.6365)\end{array}$ \\
\hline Ln Economic Active Population & $\begin{array}{l}-0.0000 \\
(0.0000)\end{array}$ & $\begin{array}{l}-0.0000 \\
(0.0000)\end{array}$ & $\begin{array}{c}-0.0000 * \\
(0.0000)\end{array}$ & $\begin{array}{l}-0.0000 \\
(0.0000)\end{array}$ & $\begin{array}{l}-0.0000 \\
(0.0000)\end{array}$ \\
\hline Infant mortality rate & $\begin{array}{l}-0.0096 \\
(0.0123)\end{array}$ & $\begin{array}{l}-0.0102 \\
(0.0110)\end{array}$ & $\begin{array}{l}-0.0099 \\
(0.0127)\end{array}$ & $\begin{array}{c}-0.0208^{* *} \\
(0.0082)\end{array}$ & $\begin{array}{l}-0.0095 \\
(0.0122)\end{array}$ \\
\hline Ln EF\&S (T-3)* & $\begin{array}{c}0.1996 * * * \\
(0.0384)\end{array}$ & $\begin{array}{c}0.1914 * * * \\
(0.0334)\end{array}$ & $\begin{array}{c}0.1869 * * * \\
(0.0376)\end{array}$ & $\begin{array}{c}0.1993 * * * \\
(0.0440)\end{array}$ & $\begin{array}{c}0.1983 * * * \\
(0.0430)\end{array}$ \\
\hline Ln PII (T-3)* & $\begin{array}{c}0.0103 \\
(0.0789)\end{array}$ & $\begin{array}{l}-0.0150 \\
(0.0786)\end{array}$ & $\begin{array}{l}-0.0097 \\
(0.0791)\end{array}$ & $\begin{array}{l}-0.0539 \\
(0.0953)\end{array}$ & $\begin{array}{c}0.0071 \\
(0.0676)\end{array}$ \\
\hline Public infrastructure stock index & $\begin{array}{c}0.1051^{* * *} \\
(0.0168)\end{array}$ & $\begin{array}{c}0.1179^{* * * *} \\
(0.0198)\end{array}$ & $\begin{array}{c}0.1128^{* * *} \\
(0.0174)\end{array}$ & $\begin{array}{c}0.0958^{* * *} \\
(0.0168)\end{array}$ & $\begin{array}{c}0.1052^{* * *} \\
(0.0171)\end{array}$ \\
\hline Ln Manufacturing employment share of total employment & $\begin{array}{c}0.5599 \\
(0.7304)\end{array}$ & $\begin{array}{c}0.5144 \\
(0.7348)\end{array}$ & $\begin{array}{c}0.5834 \\
(0.7163)\end{array}$ & $\begin{array}{c}0.6673 \\
(0.7053)\end{array}$ & $\begin{array}{c}0.5904 \\
(0.8254)\end{array}$ \\
\hline Ln Market potential & $\begin{array}{l}-0.9535 \\
(0.6219)\end{array}$ & $\begin{array}{l}-0.7970 \\
(0.5742)\end{array}$ & $\begin{array}{l}-0.8717 \\
(0.6464)\end{array}$ & $\begin{array}{c}-0.7318 \\
(0.6385)\end{array}$ & $\begin{array}{l}-0.9298 \\
(0.6085)\end{array}$ \\
\hline Ln of TGP & $\begin{array}{c}0.0226 \\
(0.5953)\end{array}$ & $\begin{array}{l}-0.1517 \\
(0.5936)\end{array}$ & $\begin{array}{l}-0.0976 \\
(0.6346)\end{array}$ & $\begin{array}{l}-0.2545 \\
(0.6582)\end{array}$ & $\begin{array}{c}0.0090 \\
(0.6118)\end{array}$ \\
\hline Ln US market potential & $\begin{array}{c}1.4898 * * * \\
(0.3955)\end{array}$ & $\begin{array}{c}1.4938 * * * \\
(0.3472)\end{array}$ & $\begin{array}{c}1.5198^{* * * *} \\
(0.4129)\end{array}$ & $\begin{array}{c}1.5754 * * * \\
(0.3616)\end{array}$ & $\begin{array}{c}1.4853 * * * \\
(0.3868)\end{array}$ \\
\hline Geographic competition EF\&S(T-3)* & & $\begin{array}{l}0.0571 \\
(0.0327)\end{array}$ & & & \\
\hline Geographic competition PII(T-3)* & & $\begin{array}{c}0.1008 \\
(0.0104)\end{array}$ & & & \\
\hline $\begin{array}{l}\text { Competition by economic specialisation EF\&S(T-3)* } \\
\text { Competition by economic specialisation PII(T-3)* }\end{array}$ & & & $\begin{array}{c}0.0682 \\
(0.0148) \\
-0.6307 * * \\
(0.0050)\end{array}$ & & \\
\hline Manufacturing employment share $\times \mathrm{EF} \& \mathrm{~S}(\mathrm{~T}-3)^{*}$ & & & & $\begin{array}{c}0.0058 * * * \\
(0.0014)\end{array}$ & \\
\hline Manufacturing employment share $\times \mathrm{PII}(\mathrm{T}-3)^{*}$ & & & & & $\begin{array}{l}-0.0003 \\
(0.0010) \\
\end{array}$ \\
\hline Obs & 162 & 162 & 162 & 162 & 162 \\
\hline \multicolumn{6}{|c|}{ Standard errors in parentheses } \\
\hline
\end{tabular}

The results are presented in table 9. Some observations sample have significant presence of manufacturing foreign/joint venture firms. It was found that the programs undertaken at the municipal level have had positive and large effects over foreign investment. The EF\&S coefficient for manufacturing firms is almost 5 times bigger than the coefficient for total foreign firms. The coefficient indicates that for $10 \%$ increase in EF\&S in the year ( $t-3)$ there has been increments in new private investments of $1.9 \%$.

Expenditures on PII showed a positive sign, yet its coefficient is not statistically significant, while, the public infrastructure stock is positive and significant. Once more time, this confirms that the local projects of infrastructure do not positively affect private investment, yet it is essential to improve local infrastructure endowments. 
The US market potential is the most important investment driver for manufacturing firms. Compared to the results for all firms, the coefficient is larger given that there are firms located in regions far from the border and some touristic places in which foreign investment do not regard with the US market, or in which the economies of scale are compensated by transport costs. Local market size and domestic market potential are not statistically significant, confirming the central role of US market for manufacturing firms, since domestic market potential is positively correlated to total of firms in table 7. It should be also remarked that one of the most important regions for foreign investment is Mexico City and its metropolitan area, which could have biased the sign and coefficient of the variable, even if it has been excluded from the sample, because all other cities close to his region have also significant foreign investments flows to take advantage of the less crowded areas, close to the biggest market in Mexico, which is also the most important financial centre.

As for economic diversity/specialisation, the column (1) the coefficient is not significant, and no conclusion can be drawn from there. Infant mortality rate has the expected sign -negative- but it is not statistically significant, neither EAP.

Competition variables in columns (2) and (3) are not statistically significant, except for ScompetitionPII. In column (1), the investment in infrastructure -PII- did not appeared statistically significant. While in column (3), it showed a negative relationship, as well as the competition variable. This confirms that that if funds destined to PII have an effect over foreign investors decisions, it may be negative, even when comparing the level of investment to other cities. At the same time, competition variables with $\mathrm{EF} \& \mathrm{~S}$ were not statistically significant in any case. In other words, the EF\&S actually have had a positive effect on new foreign investment, but it does not seem to work as a competition instrument. Indeed, as said before, upper government levels provide the most important incentives packages, which could be taken as incentives-based competition, thus comparing the level of local expenditures on EF\&S and PII between cities do not matter for foreign investors.

Finally on columns (4) and (5) are the interaction terms. The results obtained seem to indicate that EF\&S could be more effective when the share of manufacturing employment is larger in the city. Still, the manufacturing employment is not significant by itself, thus the effect is not conclusive.

\section{Discussion}

In Mexico, empirical works with cities or municipalities are rare, due to the lack of information, as well as the methodological problems when formulating a growth model. Moreover, it is believed that actions on behalf of municipal governments and their expenditures to foster investment has little or null effect, first, due to the three-partnership system, second, because of the fewer resources available in local administrations, compared to state and federal governments. The results showed that local policies matters for private investment increase. In average, for the period 1993-2008, expenditures on EF\&S showed positive effects on private investment, while PII had negative influence.

Nevertheless, when breaking to domestic/foreign total and manufacturing firms, for the period 1998-2008 the results vary a lot. Domestic firms' investment is not positively related to the interest variables. This is crucial to make a call on revising the type of investments undertaken and the way governments are helping local firms. Particularly because most programs run by municipal governments have the aim of encouraging private investment, either by making easier the paperwork, giving support for opening new firms, marketing the place, and all other actions mentioned before that are encompassed within the item EF\&S. Additionally, the infrastructure projects, are likely to respond to state government plans, adequate to the needs of foreign investors if existing, or improve basic services to households, which might not directly affect domestic private investor decisions. Still, public infrastructure stock is showed positive correlation with domestic manufacturing firms, which confirms that indeed, increasing public infrastructure endowments is beneficial, at least for this sector, meanwhile PII is not. In consequence, seeking major effectiveness in expenditures for concreting more public works should be the aim. Indeed improving infrastructure is one of the most important parts of competition in the long-term [44, 45].

Foreign investors revealed to be benefited from expenditures on EF\&S but not from PII. As said in the corresponding section, subsidies in municipal administrations are usually very small. Still, perhaps those cities spending more on EF\&S are also participating in coordination with upper government levels to get resources and incentives for foreign firms, in this way, the resources spent on EF\&S showed a positive effect, even if the amount is relatively small.

As regards with competition, the results are quite diverse for every group. These variables showed positive effects particularly in the total foreign/joint-venture firms. While for domestic firms, it was only significant GcompetitionPII. This is a remarkable result; it shows that competition is particularly significant when attracting foreign firms. Those expenditures do not regard with significant incentives, but with local competitiveness enhancement, therefore this competition is not a race to the bottom, which is a positive result. On the other side, regional competition in the case of foreign/joint venture firms showed negative effects, which could indicate a race to the bottom. 
The infrastructure endowments showed a large elasticity with the new private investment, confirming that rather than looking to offer more incentives to the enterprises the best way to make a city more attractive in economic terms, is by means of the infrastructure improvement, as well as the better education and health services that enhance labour force productivity. This is the ground to make a call to increase efforts towards improvements in physical endowments in Mexican cities. Especially, to increase the effectiveness of the expenditures, since they appeared to have the opposite effects, this could be also caused by corruption, regardless of other mismanagements and inefficiencies.

The US market is among the most important drivers for new private investment of foreign/joint-venture firms. Still, given that public infrastructure stock, EF\&S expenditures and public infrastructure stock also showed positive influence on foreign investment, investing in such policies could be good to encourage foreign investment. Nonetheless, it should not be neglected that domestic firms should receive more attention to find the reasons behind the negative correlation with municipal expenditures; especially considering that domestic firms are the main targets of municipal administrations.

Results are in line with other researchers' findings in Mexico, this is, that decentralisation, hence empowerment of local governments, tend to boost the local governments performance, and therefore have positive effects over diverse subjects. For instance, services provision [46], accountability [47], policymaking [5, 48] and wellbeing [49]. Nonetheless, as pointed out by Topal [50], the decentralisation process show different results across regions given their access to political support from the federal government and funds. Also, local stakeholders might be benefited differently, depending on their access to power means and decisions making. Which is in line with my results, domestic firms, which tend to be less represented with politicians are not benefiting from municipal policies to the extent they should, especially compared to foreign/joint venture firms.

\section{Conclusion}

The results confirm that decentralisation clearly has endowed local governments to pursue economic growth to a good extent by means of fostering private investment, actions modelled by means of the local spending on EF\&S and PII. However, given the high-dependence of local governments to the federal funds transfers, the distribution criteria is crucial. At this regard, considering that the distribution criteria of federal funds are changing to increase equalisation across regions, it might allow lagged regions to impel private investment.

Nonetheless, municipal governments should strive to attend domestic firms' demands, as they constitute the largest group in terms of production, employment and investment in the country. And the local expenditures, particularly PII are not positively influencing domestic investments, on the contrary, the outlays are positively related to foreign/joint venture investment. Moreover, since foreign/joint venture firms benefit from a larger support network and incentives provided by federal and state governments, which is not documented in this paper, it is clear that the strategies need to be redesigned. In this way, boosting domestic firms' performance must constitute the main goal for municipalities, by changing their economic strategies.

The existence of regional competition was tested and found significant in some cases. More importantly, the results suggest that competition occurs more importantly within the same region, confirming that political capitals or those getting larger decentralized funds, compared to other cities in the same region, might have better results in terms of economic outputs. Nevertheless, given the different signs and effects across firms, it is clear that competing by this mean should not be the main strategy for municipal governments.

\section{Acknowledgements}

The author thanks to the Mexican National Council for Science and Technology (Conacyt), the University of Glasgow and the Universidad Autonoma de Sinaloa for their financial support to undertake this research.

\section{REFERENCES}

[1] Cheshire, P. and S. Magrini, Urban growth drivers and spatial inequalities: Europe - a case with geographically sticky people. LEQS. Discussion paper series, 2009.

[2] Storper, M., Keys to the City: How Economics, Institutions, Social Interaction, and Politics Shape Development. Princeton University Press. 296. 2013.

[3] Rodriguez-Oreggia, E. and A. Rodriguez-Pose, The regional returns of public investment policies in Mexico. World Development. 32(9): p. 1545-1562. 2004

[4] Peña-Ahumada, J.A., Manual de transferencias federales para los municipios, I.F.p.e.F.y.e.D. Municipal, Editor. Secretaría de Gobernación: México. 2011.

[5] Lorens, J.L., F. Alburquerque, and J. Del Castillo, Estudios de caso de desarrollo económico local de América Latina. Banco Interamericano de Desarrollo: Washington D.C. 2002.

[6] Chien, S.S. and I. Gordon, Territorial Competition in China and the West. Regional Studies. 42(1): p. 31-49. 2008

[7] Sorens, J., Does Fiscal Federalism Promote Regional Inequality? An Empirical Analysis of the OECD, 1980-2005. Regional Studies. 48(2): p. 239-253. 2012 
[8] Im, T., Does Decentralization Reform Always Increase Economic Growth?: A Cross Country Comparison of the Performance. International Journal of Public Administration. 33(10): p. 508-520. 2010.

[9] Batey, P. and P. Frederich, Aspects of Regional Competition, in Regional competition. Springer: Berlin. p. 3-33. 2000.

[10] Sonis, M. and G. Hewings, Regional Competition an Complementarity: Comparative Advantages/Disadvantages and Increasing/Deceasing Returns in Discrete Relative Spatial Dynamics, in Regional Competition. Springer: Berlin. p. 139-158. 2000.

[11] Sobrino, J., Competitividad de las ciudades en México. México DF: El Colegio de México. 2003.

[12] Rodriguez-Oreggia, E., Winners and losers of regional growth in Mexico and their dynamics. Investigación Económica. LXVI (259): p. 43-62. 2007.

[13] Sanchez-Reaza, J. and A. Rodriguez-Pose, The impact of trade liberalization on regional disparities in Mexico. Growth and Change. 33(1): p. 72-90. 2002.

[14] Driscoll, J. and A. Kraay, Consistent covariance matrix estimation with spatially dependent panel data. Review of Economics and Statistics. 80(4): p. 549-560. 1998.

[15] Hoechle, D., Robust standard errors for panel regressions with cross-sectional dependence. The Stata Journal. 7(3): p. 281-312. 2007

[16] Chudik, A., M.H. Pesaran, and E. Tosetti, Weak and strong cross-section dependence and estimation of large panels. The Econometrics Journal. 14(1): p. C45-C90. 2011.

[17] De Hoyos, R. and V. Sarafidis, XTCSD: Stata module to test for cross-sectional dependence in panel data models. The Stata journal. 6(4): p. 482-496. 2006.

[18] Bond, S., A. Hoeffler, and J. Templer, GMM estimations of empirical growth models, in Discussion paper, U.o. Bristol, Editor. 2001.

[19] Roodman, D. How to do xtabond2: An introduction to difference and system GMM in Stata. The Stata Journal 9, Number 1, pp. 86-136. 2009.

[20] Malecki, E. Jockeying for position: What it means and why it matters to regional development policy when places compete. Regional Studies, 38: p. 1101-1120. 2004.

[21] Boshma, R. Competitive Regions From an evolutionary Perspective. Regional Competitiveness. London and New York: Routledge. 2004.

[22] Turok, I. Cities, Regions and Competitiveness. Regional Studies, p. 1061-1075. 2004.

[23] Thomas, K. Investment incentives and the global competition for capital. Hampshire. Palgrave Macmillan. 2011.

[24] Glaeser, E., et al., Growth in cities. Journal of Political Economy. 100 (Num. 6): p. 1126-1152. 1992.

[25] Duranton, G. and D. Puga, Diversity and specialization in cities: Why, Where and When does it matter? Urban Studies. 37(3): p. 533-555. 2000.

[26] Easterly, W.R., The elusive quest for growth: economists' adventures and misadventures in the tropics. Cambridge, Mass. London: MIT Press. xiii, 342 p. 2001.

[27] Fuentes, N.A., Desigualdades regionales en México: Los efectos de la infraestructura. (Regional Inequities in Mexico: The Impact of Infrastructure. With English summary). Comercio Exterior. 53(11): p. 1002-1010. 2003.

[28] Straub, S., Infrastructure and growth in developing countries: recent advances and research challenges. The World Bank, Policy Research Working Paper Series: 4460. 2008.

[29] Delgado, M.J. and I. Alvarez, Metodología para la elaboración de índices de equipamientos de infraestructuras productivas. Momento Económico. 117(Sept-Oct): p. 20-34. 2001.

[30] Dall'erba, S. and J. Le Gallo, Regional convergence and the impact of European structural funds over 1989-1999: A spatial econometric analysis*. Papers in Regional Science. 87(2): p. 219-244. 2008

[31] Alecke, B., T. Mitze, and G. Untiedt, Growth effects of regional policy in Germany: results from a spatially augmented multiplicative interaction model. Annals of Regional Science, 2012.

[32] Swan, T.W., ECONOMIC GROWTH and CAPITAL ACCUMULATION. Economic Record. 32(2): p. 334-361. 1956.

[33] Funck, R., Hard and Soft Determinants of Interregional Competition, in Regional Competition. Springer: Berlin. p. 66-86. 2000

[34] Camagni, R., On the Concept of Territorial Competitiveness: Sound or Misleading? Urban Studies. 39: p. 2395-2411. 2002.

[35] Storper, M., The Regional World. New York: Guilford 1997.

[36] Lever, W.F., Competitive cities in Europe. Urban Studies. 26(5-6): p. 1029-1044. 1999

[37] Camagni, R., Economia Urbana, ed. M. Girona. Barcelona: Antoni Bosh, editor, S. A. 2005

[38] FEMIA, Pro-Aereo 2012-2020. Secretaria de Economia: Mexico City. p. 99. 2012.

[39] Jordaan, J.A., Local Sourcing and Technology Spillovers to Mexican Suppliers: How Important are FDI and Supplier Characteristics? Growth and Change. 42(3): p. 287-319. 2011.

[40] Greenstone, M., R. Hornbeck, and E. Moretti, Identifying agglomeration spillovers: evidence from million dollar plants. MIT department of economics. Working series. Paper 07-31. 2010 .

[41] Rodriguez-Pose, A. and G. Arbix, Strategies of waste: Bidding wars in the Brazilian automobile sector. International Journal of Urban and Regional Research, 2001. 25(1): p. 134-154.

[42] Aitken, B.J. and A.E. Harrison, Do Domestic Firms Benefit from Direct Foreign Investment? Evidence from Venezuela. American Economic Review. 89(3): p. 605-618. 1999.

[43] Contreras, O., J. Carrillo, and J.A. Estrada, The creation of 
local suppliers within global production networks: The case of Ford Company in Hermosillo, Mexico., in The Prospects and Limits to the Development of the Automotive Periphery., D. Boleslaw, Editor. GERPISA International: Paris, France. p. 23-39. 2010

[44] Budd, L., Territorial Competition and Globalization: Scylla and Charybdis of European Cities. Urban Studies. Vol. 35(4): p. $663-685.1998$

[45] Budd, L. and A. Hirmis, Conceptual framework for regional competitiveness. Regional Studies. 38(9): p. 1015-1028. 2004.

[46] González Rivas, M., Decentralization, community participation, and improvement of water access in Mexico. Community Development. 45(1): p. 2-16. 2014.
[47] Moreno, F., Fiscal Decentralisation in Rural Local Governments in Mexico: Changes in Accountability and Entrepreneurship in the Local Government Structures. Halduskultuur. 14(1): p. 47-72. 2013.

[48] Topal, A., Global Processes and Local Consequences of Decentralization: A Sub-national Comparison in Mexico. Regional Studies, p. 1-14. 2013.

[49] Palavicini Corona, E.I., Local economic Development in Mexico. The contribution of the bottom up approach. Department of Geography and Environment. London School of Economics and Political Science: London p. 234. 2012.

[50] Topal, A., Uneven Access to Local Power: Entrepreneurial Domination in the Design of Local Development in Chihuahua, Mexico. International Journal of Urban and Regional Research. 36(6): p. 1166-1182. 2012. 